\title{
In vitro Propagation and Ex vitro Acclimatization of Potato (Solanum tuberosum L.) Using Nodal Cutting Explants
}

\author{
Othman $^{1}$, M. H. A., A. I. A. Abido ${ }^{2}$, A. A. A. jabal ${ }^{3}$ \\ ${ }^{1}$ Agricultural Research Corporation, Ministry of Agriculture and Irrigation, Republic of \\ Yemen \\ ${ }^{2}$ Plant Production Dept., Faculty of Agriculture (Saba Basha) - Alexandria University, \\ Alexandria, EGYPT
}

\begin{abstract}
Potato (Solanum tuberosum L.) is an economic tuberous crop cultivated worldwide in the temperate, tropical and subtropical zones. It occupies the fourth largest food crop following wheat, rice and maize. The aim of this study is to establish a protocol for in vitro initiation, multiplication, rooting and ex vitro acclimatization of potato plants (Solanum tuberosum L.) cultivars Lady Balfour and Bellini. This study was carried out in the plant tissue culture laboratory, the Faculty of Agriculture, Saba basha, Alexandria University, Egypt during the period from 2013 to 2016. An efficient and reliable protocol for in vitro propagation and ex vitro acclimatization of potato (Solanum tuberosum L.) was optimized. Nodal cutting explants were inoculated on various initiation or establishment media with different combinations of NAA and KIN and the neoformed shoots were cultured on proliferation (multiplication) media with different combinations of NAA and BAP for the development of multiple shoots, and the elongation media to elongate of the neoformed shoot. The subsequent elongated shoots were rooted, and acclimatized ex vitro, successfully. The best medium for shoot initiation was MS medium supplemented with $1.0 \mathrm{mg} / \mathrm{l} \mathrm{KIN}$. The favorable medium for multiplication was the tested medium augmented with $2.0 \mathrm{mg} / \mathrm{l} \mathrm{BA}$ and $0.250 \mathrm{mg} / \mathrm{l} \mathrm{NAA}$. In addition, the most effective medium for elongation was the used medium enriched with 0.250 $\mathrm{mg} / \mathrm{l} \mathrm{NAA}$. Furthermore, in vitro the shoots showed healthy root development when the tested medium was supplemented with combination of $1.0 \mathrm{mg} / \mathrm{l}$ IBA and $0.50 \mathrm{mg} / \mathrm{l} \mathrm{NAA}$ (rooting stage).The combination of sand:perlite:peatmoss (1:3:3, v:v:v) was used as substrates for the hardening of the in vitro plantlets, as a potting mix, was the best suited mix for the acclimatization of plantlets ex vitro.
\end{abstract}

Key words: In vitro culture, Solanum tuberosum L, nodal cuttings, initiation, multiplication, rhizogenesis, ex vitro acclimatization.

\section{INTRODUCTION}

The tetraploid $(2 \mathrm{n}=4 \mathrm{x}=48$ ) cultivated potato (Solanum tuberosum L.) belongs to the family solanaceae which includes tomato, eggplant, and peppers (Haque et al., $1996 \mathrm{~b}$ ). It is the fourth most cultivated food crop after wheat, rice and maize, and the most important dicotyledonous crop (Moeinil et al., 2011). The world dedicated 19.4 million tonnes per hectares in 2013 for potato cultivation. The average world farm yield for potato was 19.4 tonnes per hectare, that the world production of potatoes in 2013 was about 376.5 million tonnes and about 33 million tonnes of potato seeds (FAOSTAT, 2013).

In Egypt, potato has an important position among all vegetable crops, where about $20 \%$ of total area devoted for vegetable production was cultivated with it and the cultivated area of potato was 165000 hectares and its production was 4.5 million metric tonnes (MT) and about 408,000 MT of potato seeds. Potato ranks second in the list of the Egyptian agricultural exports after cotton, of which 171.012 
metric tonnes were export to Europe and some Arab countries for 2013 seasons (FAOSTAT, 2013).

In Egypt, importation of certified potato tubers costs very high. Therefore, alternative methods to obtain potato tubers which can be practiced locally and maintain free of diseases have to find, one of these methods is in vitro propagation.

Potato is highly amenable to tissue culture micropropagation has became established methods of rapidly multiplying cultivars for potato production as well as for germplasm conservation (Donnelly et al., 2003 and Gopal et al., 2005). The main advantage of potato micropropagation technology is the production of high quality and uniform plantlets (Naik and Karihaloo, 2007).

Tissue culture techniques are used to propagate potato in vitro. Therefore, potato propagation through in vitro multiplication results in the rapid production of high quality disease-free-seed potatoes (Nistor et al., 2010). As a result, it can solve the limitations that conventionally propagation through tubers had: low multiplication rate and susceptibility to pathogens (Badoni and Chauhan, 2010). In vitro propagation methods using sprouts and nodal cutting are more reliable for maintaining genetic integrity of the multiplied clones (Liljana et al., 2012).

Furthermore, transferring of tissue culture - derived plantlets to ex vitro (acclimatization) is the most critical stage within tissue culture cycle (Abido, 2016). It is known that shoots or plantlets grown in vitro are survive under artificial environment, subsequently their growth is not normal; these plant materials have different anatomical and physiological then those morphological characteristics due to their growth in vitro ( Pospisilova et al., 1999). Than, Transferring there materials to ex vitro conditions need such acclimatization which differ greatly from in vitro conditions (Hossain et al., 2009). Among such factors affecting the hardening - off is the potting mixture.

The present study was aimed to establish an efficient and reliable protocol for in vitro propagation and ex vitro acclimatization of potato via nodal cuttings as initial explants of two potato cultivars coined as Lady Balfour and Bellini.

\section{MATERIALS AND METHODS}

The experiments regarding the effect of different concentrations of certain growth regulators and their combinations on micropropagation of potato (Solanum tuberosum L.) plantlets using nodal cuttings as explants were conducted at the Plant Tissue Culture Laboratory, the Faculty of Agriculture Saba Basha, Alexandria University, during the period from 2013 to 2016.

\section{Plant materials:}

Two commercial and certified potato (Solanum tuberosum L.) cultivars i.e. Lady Balfour and Bellini were used in this study. Both cultivars were obtained from 
the General Committee of Potato Production, the Egyptian company for importation and storage of potato.

\section{Explants preparation and sterilization:}

The given tubers were brushed and washed under running water to exclude mud, dirties, and soaked in gibberellin $\left(\mathrm{GA}_{3}\right)$ solution concentration of $0.10 \mathrm{~g} / \mathrm{l}$ for a period of 1-2 hours, then sprightly washed and kept in closed paper bag at $24{ }^{\circ} \mathrm{C}$ until small sprouts appeared (ca. 14 days).

The sprouts of $0.5-1 \mathrm{~cm}$. were collected from the mother plants (i.e. Lady Balfour and Bellini cultivars) in beaker filled with water and kept under running water prior to sterilization in the laminar airflow cabinet. The excised eye buds (sprouts) were rinsed in distilled water, dipped in $70 \%$ Ethanol alcohol $\left(\mathrm{C}_{2} \mathrm{H}_{5} \mathrm{OH}\right)$ for one minute, stirred in $0.1 \%$ mercuric chloride $\left(\mathrm{HgCl}_{2}\right)$ for 3-5 minute with a few drops of wetting agent "Tween-80" (surfactant agent) for five minutes (llahi et al., 2007). After the surface sterilization of explants was completed, mercuric chloride was decanted and the explants were rinsed with double distilled water thrice, so as to lower the toxic effects of $\mathrm{HgCl}_{2}$ and became ready for manipulation in vitro. To overcome phenols' formation materials, they were put in an antioxidant-sterilized solution (100 mg/l ascorbic acid and $150 \mathrm{mg} / \mathrm{l}$ citric acid) for 10 minutes. Finally, shoot tip explants of the initiated sprouts were rinsed with sterile distilled water three times and became ready to culture in vitro.

\section{Micropropagation stages:}

\section{Initiation stage:}

Explants (shoot tips) were cultured on solidified Murashige and Skoog medium (1962) which solidified with gelrite $(3 \mathrm{~g} / \mathrm{l})$. However, the $\mathrm{pH}$ of the tested media was adjusted to 5.7 before adding gelrite, then sterilized autoclaving at $121^{\circ} \mathrm{C}$ for $20 \mathrm{~min}$. On cooling of the media, four sterilized shoot tip explants (0.3$0.5 \mathrm{~cm})$ were cultured on the given MS media which contained different concentrations of cytokinin (KIN) at five concentrations: 0.000 (nil), $0.125,0.25$, 0.50 and $1.0 \mathrm{mg} / \mathrm{l}$, in combinations with auxin (NAA) at three concentrations: 0.000 (nil), 0.125 and $0.250 \mathrm{mg} / \mathrm{l}$.

\section{Multiplication stage:}

For in vitro multiplication of virus-free-shoot clone, stock plants were obtained through shoot tip outgrowth using their nodal cuttings with 2 nodes. The excised nodal cuttings explants of the different positions were cultured, randomly, in the multiplication media which supplemented with $1^{\circ}$ multiplication treatments' combination between BAP and NAA at $(0.00$ nil, $0.25,0.50,1.00,2.00)$ and $(0.000$ [nil], 0.125, 0.250) mg/l, respectively.

\section{Rooting (rhizogenesis) stage:}

The obtained shoots of both potato (Solanum tuberosum L.) cultivars from the multiplication stages were, individually, separated or excised and cultured on a 
rooting medium. The medium contained MS salts, sucrose at $30 \mathrm{~g} / \mathrm{l}$. For rooting, two types of auxins were tested; whereas IBA was at four concentrations: 0.000 (nil), $0.250,0.500$ and $1.000 \mathrm{mg} / \mathrm{l}$, designed as factorial experiments layout in completely randomized design (Gomez and Gomez, 1984). Recorded data were analyzed statistically using analysis of variance technique combinations with NAA at three concentrations: 0.000 (nil), 0.250 and $0.500 \mathrm{mg} / \mathrm{l}$.

Generally, each treatment was represented by 3 jars and four explants in each jar $(175 \mathrm{ml})$ containing $20 \mathrm{ml}$ medium. Cultured explants were placed, vertically. Each treatment was replicated three times and each replication has 4 explants. The jars were capped with polypropylene closures.

The culture jars and the tested media were solidified and autoclaved as mentioned - earlier. The explants were cultured on the sterilized media, vertically, and incubated in growth room at $25 \pm 1^{\circ} \mathrm{C}$, illuminated with fluorescent lamps (Philips) located $40 \mathrm{~cm}$ above the culture jars, giving an average irradiance (ca. $40 \mu \mathrm{mol} / \mathrm{m}^{2} / \mathrm{s}$ ). High illumination regimes were set at $16 \mathrm{hr}$. photoperiods for four weeks to produce in vitro virus-free-plantlet.

\section{Acclimatization of neoformed plantlets:}

The plantlets produced from rooting stage of both cultivars were washed out of solidified medium under running tap water, followed by immersing them into Rizolex-T50 WP (1g/l) [From Sumitomo Chemical Co. Ltd., Osaka, Japan] fungicide for $25 \mathrm{sec}$. They were, then, transplanted ex vitro in small plastic pots (10 $\mathrm{cm})$. For both cultivars, plastic pots contained an autoclaved mixture of the perlite $(0,1,2,3$, volume $)$ and peatmoss $(0,1,2,3$, volume); and one constant volume of washed and autoclaved sand.

The perlite has a bulk density of about $\left(0.03-0.150 \mathrm{~g} / \mathrm{cm}^{3}\right)$ and porosity about $95 \%$, while the peatmoss has a bulk density of about $\left(0.250 \mathrm{~g} / \mathrm{cm}^{3}\right)$ and porosity about (95-98\%). Then, they were arranged in a factorial experiment and finally placed in transparent plastic bags (ex vitro), to maintain high relative humidity at $80 \%(\mathrm{RH})$ and $28 \pm 1^{\circ} \mathrm{C}$, for hardening-off. However, the tested pots with different media were rearranged' randomly, weekly within same plot to devoid the experimental error.

Ten days later, the plastic bags were perforated for gaseous exchange, then transferred into plastic house (in vivo) and continued for further hardening. After three weeks, the plastic bags were removed and the acclimatized plantlets were watered, as needed and fertilized, weekly, with $\mathrm{N}: \mathrm{P}_{2} \mathrm{O}_{5}: \mathrm{K}_{2} \mathrm{O}(20: 20: 20)$ equivalent to1g/l (AGRO 4).

Generally, the following characters were recorded per propagule at initiation, multiplication and rooting stages for both tested cultivars after four weeks in culture: 
1. Average number of neoformed shoots / propagule.

2. Average shoots lengths $(\mathrm{cm}) /$ propagule.

3. Average number of nodes formed/propagule.

4. Average number of leaflets formed / propagule.

5. Average number of roots formed / propagule.

6. Average root length $(\mathrm{cm}) /$ propagule (at rooting stage).

Concerning the Acclimatization stage, the following traits were determined:

1. Average survival percentage (\%) / plant.

2. Average plant height $(\mathrm{cm}) /$ plant.

3. Average number of neoformed branches / plant.

\section{Statistical analysis}

All the experiments carried out during this study were designed as factorial experiments layout in completely randomized design (Gomez and Gomez, 1984). Recorded data were analyzed statistically using analysis of variance technique (ANOVA) Steel et al. (1997). The means significance was compared by applying the Least Significant Difference (L.S.D.) test at 5\% level of probability.

\section{RESULTS AND DISCUSSION}

Achievement of optimal and reliable system for micropropagation of Potato (Solanum tuberosum L.) was urgent and in focus. Therefore, a set of experiments was conducted, and the obtained results were presented and discussed in the following sections as follows:

\section{Initiation stage:}

This stage aimed to reach the best combination of both KIN and NAA for producing virus-free plantlets for both original cultivars of potatoes "Lady Balfour" and "Bellini". Murashige and Skoog (1962) basal nutrients medium (MS) and 30g/l sucrose, supplemented with various concentrations of KIN in combination with NAA (mg/l) used for initiation stage.

The results of initiation stage of both tested cultivars, i.e. "Lady Balfour and Bellini" are shown in Tables (1and 2) and Figures (1 and 2), each in turn. The recorded data indicated similar performance; whereas, the different levels of KIN and NAA (mg/l) and their interactions; exerted significant effects on the studied traits.

Pertaining the main effect of KIN on initiation stage of "Lady Balfour and Bellini" cvs, the obtained results divulged that there were direct proportional relationships between the tested levels of KIN and the given traits for both cultivars. As KIN levels, increase the average values of both cultivars increased for all studied traits, especially at the higher level $(1.000 \mathrm{mg} / \mathrm{l})$ and vice versa. As for Lady Balfour cv. (Table 1), at the defined level $(1.000 \mathrm{mg} / \mathrm{l})$, the highest average of the number of neoformed shoots, shoot length, number of nodes, leaflets and roots 
formed per propagule, as 7.78, $8.63 \mathrm{~cm}, 8.22,9.22$ and 9.11, respectively. Meanwhile, the lowest averages of studied traits were achieved on KIN - free medium (0.000 mg/l). Regarding "Bellini" (Table 2), similar performance was noticed as the earlier cultivar; whereas at $1.000 \mathrm{mg} / \mathrm{l}$ of $\mathrm{KIN}$, the highest average values were recorded when culture MS medium was augment with the above mentioned level (i.e. $1.000 \mathrm{mg} / \mathrm{l}$ ) and vice versa. At the defined KIN level, resulted in the highest average of the number of neoformed shoots, shoots length, number of nodes, leaflets and roots formed per propagule, as $8.56,8.98 \mathrm{~cm}, 7.78,8.78$ and 9.78 , consecutively.

With respect to the main effect of NAA on initiation stages of both cultivars, Tables (1and 2) whereas, there were negative relationships between the given levels and the studied traits except the average number of roots formed per propagule, and vice versa.

Regarding "Lady Balfour" cv., data of Table (1) expressed as the highest averages of the number of neoformed shoots, shoots length, number of nodes and leaflets formed per propagule, were $6.93,7.03 \mathrm{~cm}, 6.73$ and 7.73 , orderly at 0.000 (nil) NAA. Meanwhile, the highest average number of roots formed per propagule, viz 8.07, when the culture medium was fortified with $0.250 \mathrm{mg} / \mathrm{l}$ (NAA).

In similar performance "Bellini" cv. Table (2), expressed as the highest averages for the tested traits e.g. number of neoformed shoots, shoots length, number of nodes and leaflets as $7.27,7.68 \mathrm{~cm}, 6.80,7.80$ when the culture medium was NAA free - hormone. Meanwhile, augmenting the culture medium with $0.250 \mathrm{mg} / \mathrm{l}$ led to the highest average number of roots formed per propagule (8.73). Pertaining the interaction between both applied growth regulators on the initiation stage studied traits of "Lady Balfour" cv., revealed that MS culture medium, with KIN at $1.000 \mathrm{mg} / \mathrm{l}$ and NAA - free - medium, resulted in the highest averages of studied traits, except for average number of roots formed per propagule; whereas MS with KIN at $1.000 \mathrm{mg} / \mathrm{l}+\mathrm{NAA}$ at $0.250 \mathrm{mg} / \mathrm{l}$, brought about the highest average value. As for the cv. "Bellini", similar performance was clear.

The obtained data could be taken place due to the mode of action of cytokinins as kinetin (KIN), which is taken part in the regulation of cell cycle in plant cells (i.e. regulation of cell division), shoot formation and delay of plant senescence.

Also cytokinins play a critical role, which act as anti-auxin effects (i.e. inhibition of the oxidation of IAA. For instance, KIN (0.04- $1.00 \mathrm{mg} / \mathrm{l})$ alters the activity, distribution, and composition of IAA.IAA oxidase enzymes within tobacco callus cells (Lee, 1974), enhancing the branching (i.e. professing axillary shoots) and reducing apical dominance (George et al., 2008). Despite the opposite observation of cytokinins on root initiation as inhibition or delay of root formation (Schraudolf and Reinert, 1959; Harris and Hart, 1964 and Ben - Jaccov et al., 
1991), and prevent root growth and promotive effects of auxins on root initiation (Humphries, 1960).

Also, there are reports indicate that cytokinins can sometimes induce or promote root growth (Fries, 1960), or adventitious root formation, in the absence of auxins (Nemeth, 1979). In nearly, all cases only low rates of cytokinins have been effective (George et al., 2008). For example, shoots of sugar beet were rooted on MS medium containing $0.5 \mathrm{mg} / \mathrm{K} \mathrm{KIN}$ and no auxin (Konwar and Coutts, 1990).

The auxins as NAA almost invarialily required to promote the initial growth of plant explants. For instance, George et al. (2008) stated that a low concentration of auxin is often beneficial in conjunction with high levels of cytokinin at tissue culture cycle and especially at multiplication stage when shoot multiplication is required, although in some cases cytokinin alone is sufficient.

The indiction of rhizogenesis usually requires an adjustment in the levels of auxins and cytokinins. Boxus and Terzi (1988) advocated the addition of $0.5 \mathrm{mg} / \mathrm{l}$ KIN and auxin to the rooting media for strawberries and several woody plants, finding that at this concentration, the cytokinin had a bacteriostatic effect and rooting was not impaired. For instance, Rosa hybrid 'White Dream' cv. required the addition of $1.00 \mathrm{mg} / \mathrm{I} \mathrm{IBA}$ to BA for root induction and development (George et al., 2008). Lam (1977) studied the effect of auxin: Kinetin ratio in the nutrient medium for proliferation of tuber discs of cV. spunta and found that the addition of $0.2 \mathrm{mg} / \mathrm{l}$ NAA to the medium appeared to adjust the ratio to the points where normal plantlets with both shoots and roots were produced in a single step.

Regarding the auxin - cytokinin interaction, the balance between auxin and cytokinin growth regulators is most often required for formation of shoots and roots (i.e. organogenesis) as reported by George et al. (2008).

The combination of Kinetin and NAA had consistently given good result for improving shoot length of potato. Low concentration of Auxin ( $0.1 \mathrm{mg} / \mathrm{NAA}$ ) plus moderate concentration of cytokinine $(0.01 \mathrm{mg} / \mathrm{l}$ Kinetin) showed good development of complete plantlets from meristem tips of potato (Badoni and Chauhan, 2009).

Hoque (2010) showed the best shoot and root regeneration on MS medium with $2 \mathrm{mg} / \mathrm{l} \mathrm{KIN}$ and IAA, whereas Badoni and Chauhan (2009) detected lower concentration of NAA $(0.01 \mathrm{mg} / \mathrm{l})$ with Gibberelic Acid $(0.25 \mathrm{mg} / \mathrm{l})$ as the best combination for the regeneration of complete plantlets from meristem tips. 
Table (1). The effect of different levels of KIN and NAA (mg/l) and their combinations on the initiation stage of Lady Balfour potato culture cultivar after four weeks in vitro.

\begin{tabular}{|c|c|c|c|c|c|c|c|c|c|c|}
\hline \multirow{3}{*}{ Characters } & \multirow{3}{*}{$\begin{array}{c}\text { NAA } \\
\text { levels } \\
\text { (mg/l) }\end{array}$} & \multicolumn{5}{|c|}{ KIN levels (mg/l) } & \multirow{3}{*}{$\begin{array}{c}\text { Average } \\
\text { NAA }\end{array}$} & \multicolumn{2}{|c|}{ Significance } & \multirow{3}{*}{$\begin{array}{c}\text { KIN } \\
X \\
\text { NAA }\end{array}$} \\
\hline & & \multirow{2}{*}{0.00} & \multirow{2}{*}{0.125} & \multirow[b]{2}{*}{0.250} & \multirow[b]{2}{*}{0.500} & \multirow[b]{2}{*}{1.000} & & \multirow{2}{*}{ KIN } & \multirow[b]{2}{*}{ NAA } & \\
\hline & & & & & & & & & & \\
\hline \multicolumn{11}{|c|}{ (a) Average number of neoformed shoots / propagule } \\
\hline & 0.000 & 6.33 & 6.67 & 6.67 & 6.67 & 8.33 & $6.93 a$ & ** & ** & * \\
\hline & 0.125 & 3.67 & 5.33 & 5.33 & 6.33 & 7.33 & $5.60 \mathrm{~b}$ & & & \\
\hline & 0.250 & 3.67 & 5.00 & 5.33 & 6.67 & 7.67 & $5.67 \mathrm{~b}$ & & & \\
\hline Average(KIN) & & $4.56 \mathrm{~d}$ & $5.67 \mathrm{c}$ & $5.78 \mathrm{c}$ & $6.56 \mathrm{~b}$ & $7.78 \mathrm{a}$ & & & & \\
\hline \multicolumn{8}{|c|}{ L.S.D. (0.05) } & 0.59 & 0.46 & 1.03 \\
\hline \multicolumn{11}{|c|}{ (b) Average shoot length (cm) / propagule: } \\
\hline & 0.000 & 4.80 & 6.97 & 6.93 & 7.03 & 9.40 & $7.03 a$ & ** & ** & ** \\
\hline & 0.125 & 4.40 & 5.97 & 6.17 & 6.80 & 8.10 & $6.29 \mathrm{~b}$ & & & \\
\hline & 0.250 & 4.53 & 5.70 & 5.87 & 7.33 & 8.40 & $6.37 \mathrm{~b}$ & & & \\
\hline Average(KIN) & & $4.58 \mathrm{~d}$ & $6.21 \mathrm{c}$ & $6.32 b$ & $7.06 \mathrm{~b}$ & $8.63 a$ & & & & \\
\hline \multicolumn{8}{|c|}{ L.S.D. (0.05) } & 0.18 & 0.14 & 0.32 \\
\hline
\end{tabular}

(c) Average number of nodes formed / propagule:

\begin{tabular}{|c|c|c|c|c|c|c|c|c|c|c|}
\hline & 0.000 & 4.33 & 6.00 & 7.00 & 7.33 & 9.00 & $6.73 a$ & $* \star$ & ** & $* *$ \\
\hline & 0.125 & 4.00 & 5.33 & 5.67 & 6.00 & 7.67 & $5.73 b$ & & & \\
\hline & 0.250 & 4.67 & 4.67 & 4.67 & 7.33 & 8.00 & $5.87 \mathrm{~b}$ & & & \\
\hline Average(KIN) & & $4.33 d$ & $5.33 c$ & $5.78 \mathrm{c}$ & $6.89 \mathrm{~b}$ & $8.22 a$ & & & & \\
\hline \multicolumn{8}{|c|}{ L.S.D. (0.05) } & 0.50 & 0.39 & 0.86 \\
\hline
\end{tabular}

(d) Average number of leaflets formed / propagule:

\begin{tabular}{|c|c|c|c|c|c|c|c|c|c|c|}
\hline & 0.000 & 5.33 & 7.00 & 8.00 & 8.33 & 10.00 & 7.73a & $* *$ & $* *$ & $* *$ \\
\hline & 0.125 & 5.00 & 6.33 & 6.67 & 7.00 & 8.67 & $6.73 b$ & & & \\
\hline & 0.250 & 5.67 & 5.67 & 5.67 & 8.33 & 9.00 & $6.87 \mathrm{~b}$ & & & \\
\hline Average(KIN) & & $5.33 d$ & $6.33 c$ & $6.78 c$ & $7.89 b$ & $9.22 a$ & & & & \\
\hline \multicolumn{8}{|c|}{ L.S.D. (0.05) } & 0.50 & 0.39 & 0.86 \\
\hline
\end{tabular}

(e) Average number of roots formed / propagule:

\begin{tabular}{|c|c|c|c|c|c|c|c|c|c|c|}
\hline & 0.000 & 6.67 & 6.67 & 7.33 & 8.00 & 6.67 & $6.87 c$ & ** & $* *$ & ** \\
\hline & 0.125 & 6.67 & 6.67 & 8.00 & 7.67 & 9.67 & $7.53 b$ & & & \\
\hline & 0.250 & 7.33 & 7.33 & 7.00 & 9.33 & 11.00 & $8.07 a$ & & & \\
\hline Average(KIN) & & $5.67 d$ & $6.89 c$ & $7.44 \mathrm{c}$ & $8.33 b$ & $9.11 a$ & & & & \\
\hline \multicolumn{8}{|c|}{ L.S.D. (0.05) } & 0.69 & 0.63 & 1.20 \\
\hline
\end{tabular}

- Mean values followed by the same letter (s), are not different significantly.

- L.S.D. $(0.05)=$ Least significant difference test at 0.05 level of probability.

$-{ }^{*},{ }^{* *}, \mathrm{NS}=$ significant, high significant, not significant, respectively. 
Table (2). The effect of different levels of KIN and NAA (mg/l) and their combinations on the initiation stage of Bellini potato culture cultivar after four weeks in vitro.

\begin{tabular}{|c|c|c|c|c|c|c|c|c|c|c|}
\hline \multirow[b]{2}{*}{ Characters } & \multirow{2}{*}{$\begin{array}{c}\text { NAA } \\
\text { levels } \\
\text { (mg/l) }\end{array}$} & \multicolumn{5}{|c|}{ KIN levels (mg/l) } & \multirow{2}{*}{$\begin{array}{c}\text { Average } \\
\text { NAA }\end{array}$} & \multicolumn{2}{|c|}{ Significance } & \multirow{2}{*}{$\begin{array}{c}\text { KIN } \\
X \\
\text { NAA }\end{array}$} \\
\hline & & 0.00 & 0.125 & 0.250 & 0.500 & 1.000 & & KIN & NAA & \\
\hline \multicolumn{11}{|c|}{ (a) Average number of neoformed shoots / propagule } \\
\hline & 0.000 & 6.67 & 7.00 & 7.00 & 7.00 & 8.67 & $7.27 \mathrm{a}$ & ** & ** & ** \\
\hline & 0.125 & 4.00 & 5.67 & 5.67 & 7.33 & 8.33 & $6.20 \mathrm{~b}$ & & & \\
\hline & 0.250 & 4.67 & 6.00 & 5.67 & 7.33 & 8.67 & $6.47 \mathrm{~b}$ & & & \\
\hline Average(KIN) & & $5.11 d$ & $6.22 \mathrm{c}$ & $6.11 \mathrm{c}$ & $7.22 b$ & $7.78 a$ & & & & \\
\hline \multicolumn{8}{|c|}{ L.S.D. (0.05) } & 0.57 & 0.45 & 0.99 \\
\hline \multicolumn{11}{|c|}{ (b) Average shoot length (cm) / propagule: } \\
\hline & 0.000 & 5.60 & 7.73 & 7.80 & 7.87 & 9.40 & $7.68 a$ & ** & ** & ** \\
\hline & 0.125 & 5.27 & 6.83 & 6.97 & 7.60 & 8.83 & $7.10 \mathrm{~b}$ & & & \\
\hline & 0.250 & 5.37 & 6.50 & 6.73 & 8.17 & 8.70 & $7.09 b$ & & & \\
\hline Average(KIN) & & $5.41 d$ & $7.02 \mathrm{c}$ & $7.17 b$ & $7.88 \mathrm{~b}$ & $8.98 a$ & & & & \\
\hline \multicolumn{8}{|c|}{ L.S.D. (0.05) } & 0.18 & 0.14 & 0.31 \\
\hline \multicolumn{11}{|c|}{ (c) Average number of nodes formed / propagule: } \\
\hline & 0.000 & 5.33 & 6.33 & 7.33 & 7.33 & 7.67 & $6.80 a$ & ** & ** & * \\
\hline & 0.125 & 4.67 & 5.33 & 4.67 & 6.67 & 7.67 & $5.80 \mathrm{~b}$ & & & \\
\hline & 0.250 & 4.67 & 5.33 & 5.33 & 6.67 & 8.00 & $6.00 \mathrm{~b}$ & & & \\
\hline Average(KIN) & & $4.89 d$ & $5.67 \mathrm{c}$ & $5.78 \mathrm{c}$ & $6.89 b$ & $7.78 a$ & & & & \\
\hline \multicolumn{8}{|c|}{ L.S.D. (0.05) } & 0.54 & 0.42 & 0.93 \\
\hline \multicolumn{11}{|c|}{ (d) Average number of leaflets formed / propagule: } \\
\hline & 0.000 & 6.33 & 7.33 & 8.33 & 8.33 & 8.67 & $7.80 \mathrm{a}$ & ** & ** & * \\
\hline & 0.125 & 5.67 & 6.33 & 5.67 & 7.67 & 8.67 & $6.80 \mathrm{~b}$ & & & \\
\hline & 0.250 & 5.67 & 6.33 & 6.33 & 7.67 & 9.00 & $7.00 \mathrm{~b}$ & & & \\
\hline Average(KIN) & & $5.89 d$ & $6.67 \mathrm{c}$ & $6.78 \mathrm{c}$ & $7.89 b$ & $8.78 a$ & & & & \\
\hline \multicolumn{8}{|c|}{$\begin{array}{ll}\text { L.S.D. (0.05) } \\
\end{array}$} & 0.54 & 0.42 & 0.93 \\
\hline \multicolumn{11}{|c|}{ (e) Average number of roots formed / propagule: } \\
\hline & 0.000 & 6.33 & 7.33 & 8.00 & 8.67 & 7.33 & $7.53 c$ & ** & ** & ** \\
\hline & 0.125 & 6.33 & 7.67 & 8.67 & 8.33 & 10.33 & $8.20 b$ & & & \\
\hline & 0.250 & 6.33 & 8.00 & 7.67 & 10.00 & 11.67 & $8.73 a$ & & & \\
\hline Average(KIN) & & $6.33 d$ & $7.56 \mathrm{c}$ & $8.11 \mathrm{c}$ & $9.00 \mathrm{~b}$ & $9.78 a$ & & & & \\
\hline \multicolumn{8}{|c|}{ L.S.D. (0.05) } & 0.56 & 0.43 & 0.96 \\
\hline
\end{tabular}

- Mean values followed by the same letter (s), are not different significantly.

- L.S.D. (0.05) = Least significant difference test at 0.05 level of probability.

$-{ }^{*},{ }^{* *}, \mathrm{NS}=$ significant, high significant, not significant, respectively. 


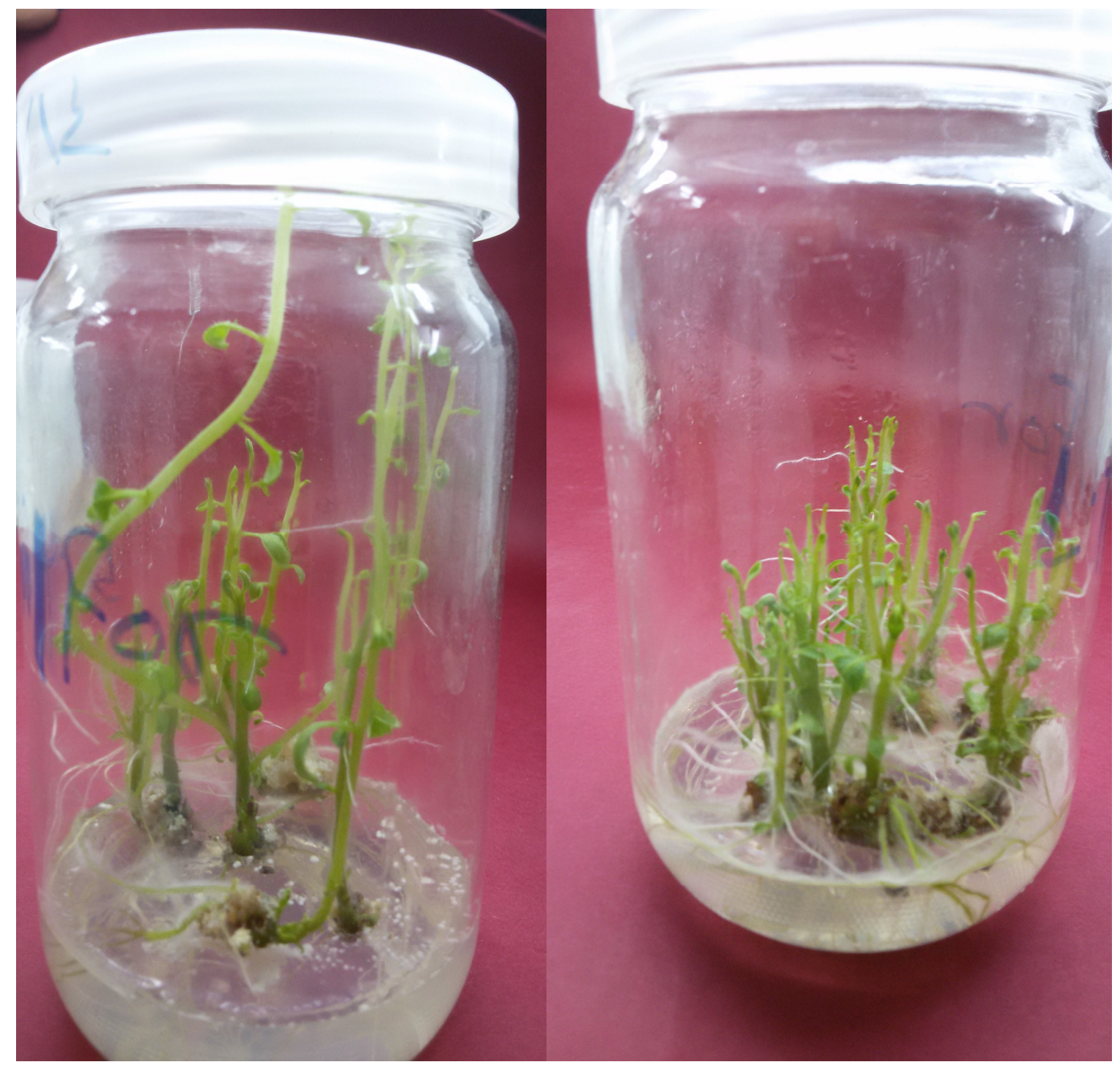

Figure (1): Lady Balfour cv.

Figure (2): Bellini cv.

Figures (1and2). Initiation stage of both potato cultivars shoot tip explants cultured for 4 weeks on MS medium supplemented with KIN and NAA at 1.000 and $0.250 \mathrm{mg} / \mathrm{l}$, respectively. 


\section{Multiplication stage:}

The results of multiplication stage of both tested cultivars are shown in Tables (3and 4) and Figures (3and 4). The tabulated results of both cultivars are expressed similar trend; whereas, the various levels of BAP and NAA (mg/l) and their interactions; practiced significant effects on the studied characters.

Respecting the main effect of BAP on multiplication stage of both "Lady Balfour and Bellini" cvs, the obtained results disclosed that augmenting the culture medium with $2.00 \mathrm{mg} / \mathrm{BAP}$; resulted in the highest average values of studied traits for both cultivars. As for "Lady Balfour" cv. (Table 3 and Fig. 3), at the above mentioned concentration (2.00 mg/l BAP) produced the highest averages of shoot length, number of nodes, neoformed shoots, leaflets and number of roots formed per propagule, as $8.17 \mathrm{~cm}, 10.22,12.34,11.22$ and 9.11 , consecutively. Meanwhile, the lowest averages of tested traits were achieved at $0.250 \mathrm{mg} / \mathrm{l}$, but the lowest number of roots was true at BAP - free - medium.

Regarding "Bellini" cv., as shown in Table (4) behaved similarly as the former cultivar; whereas, the highest averages the studied traits, viz. the highest averages of shoot length, number of nodes, neoformed shoots, leaflets and number of roots formed per propagule were achieved upon fortified the culture media with BAP at $2.00 \mathrm{mg} / \mathrm{l}$, as $8.94 \mathrm{~cm}, 11.89,12.00,12.89$ and 9.89, orderly. Meanwhile, the lowest averages were recorded when BAP was added at 0.250 $\mathrm{mg} / \mathrm{l}$.

With reference to the main effect of NAA adding NAA at $0.250 \mathrm{mg} / \mathrm{l}$, brought about the highest averages of the studied traits, as shoot length, number of nodes, neoformed shoots, leaflets and roots formed per propagule were $8.78 \mathrm{~cm}, 9.53$, $10.87,10.53$ and 8.47 , consecutively.

As for the interaction between both applied growth regulators on multiplication stage of both cultivars, augmenting the culture media with BAP and NAA at 2.00 and $0.250 \mathrm{mg} / \mathrm{l}$ brought about the highest averages of all studied traits.

In general, these results could be brought about to the cytokinins mode of action of on stimulation both cell division and promotion growth of axillary shoots in plant tissues culture as, also, found by Tamas(1987), Triginano and Gray (2000) and George et al. (2008).

After shoot regeneration, multiplication of shoots was obtained on MS basal medium supplemented with BAP $(2.00 \mathrm{mg} / \mathrm{l})$. It was observed that BAP played important role in shoot regeneration. It was observed that BAP played important role in shoot regeneration. Similar results were reported by Yasmin et al. (2003) who obtained maximum number of shoots by using BAP at $2 \mathrm{mg} / \mathrm{l}$. The similar 
results were, also, obtained by khatun et al. (2003). Earlier reports are available on role of BAP in promoting the number of lateral shoot (Uddin, 2002; Hussain et al., 2005 and Motallebi-Azar, et al., 2011). Similar results were, also, reported by Sarker and Mustafa (2002) that the BAP showed better response in terms of shoot per explants, shoot length, number of nodes and leaves in potato varieties "Lal Pari and Jam Alu". Similar behavior was also observed in varieties as "Diamont, Altamash and Cardinal". The obtained results coincide with the reports of Hoque et al. (1996a, 1996b) and Mila (1991) for other potato varieties. Hussain et al. (2005) obtained maximum regeneration percentage from nodal explants of potato on MS basal medium with $2.0 \mathrm{mg} / \mathrm{l} \mathrm{BAP}$ and $0.5 \mathrm{mg} / \mathrm{l}$ IAA. Molla et al. (2011) also studied the effect of growth regulators on direct regeneration of potato.

However, BAP stimulates the growth of lateral buds, whereas NAA decreases single nodes growth and rooting of potato plantlets (Moeinil et al., 2011). However, the growth of explants is slow in such hormones free, cost effective media. Otherwise, the growth rate of explant can be improved by supplementing medium with growth regulators (Yousef et al., 2001 and Hoque, 2010). Ammirato (2004) reported that cytokinin at moderate concentrations enhances shoot development. BAP has significant role in cell multiplication, therefore, number of shoots also increased. Also, BA up to 1.0 and $1.5 \mathrm{mg} / \mathrm{l}$ showed an increase in number of proliferated shoots and number of nodes /flask (Espinoza et al., 1992). It was also observed that BAP played as important role in shoot formation. For instance at lower concentration, shoot numbers were 0.83 but it increased gradually with increase in BAP to 5.00 (lqbal et al., 2005). Percentage of explants producing shoots significantly varied due to the different concentration of BAP. For example, $100 \%$ explants survived and produced shoots on BAP at 2 and $3 \mathrm{mg} / \mathrm{l}$ (Molla et al., 2011). On the other hand, in the absence of NAA which gave the highest mean values could be attributed to the mode of action of endogenous level of auxin which was optimal to achieve these results, which showed that beyond all measurements in the absence of NAA followed by lower level to higher. Therefore, higher concentration of NAA responded the least mean shoot height and number followed of nodes. This could be attributed to the fact that higher concentration of NAA inhibits root and shoot growth (Pennazio and Vecchiati, 1976). In this study most of the positive outcomes resulting from the overlap of both organizations growth regulators, recorded in the absence or low concentrations of both BAP and NAA. Similar results were reported by Sanavy and Moeini (2003). The previous authors showed such significant differences between MS medium and MS medium supplemented with BAP and NAA. There were significant differences between "Agria and Marfona" cultivars. The modified solid (MS) without NAA and BAP was found to be best for the formation of roots and shoots. On the other hand, BAP at low concentrations $(0.00$ or $0.50 \mathrm{mg} / \mathrm{l})$ was the optimal and showed a significant effect on almost parameters for cultivar Rosetta. 
Table (3). The effect of different levels of BAP and NAA (mg/l) and their combinations on the multiplication stage using nodal cutting for Lady Balfour potato cultivar after four weeks in vitro.

\begin{tabular}{|c|c|c|c|c|c|c|c|c|c|c|}
\hline \multirow[b]{2}{*}{ Characters } & \multirow{2}{*}{$\begin{array}{l}\text { NAA } \\
\text { levels }\end{array}$} & \multicolumn{5}{|c|}{ BAP levels (mg/l) } & \multirow{2}{*}{$\begin{array}{c}\text { Average } \\
\text { NAA }\end{array}$} & \multicolumn{2}{|c|}{ Significance } & \multirow[b]{2}{*}{ BAP X NAA } \\
\hline & & 0.00 & 0.25 & 0.50 & 1.00 & 2.00 & & BAP & NAA & \\
\hline
\end{tabular}

(a) Average number of neoformed shoots / propagule

\begin{tabular}{|c|c|c|c|c|c|c|c|c|c|c|}
\hline & 0.000 & 11.00 & 6.67 & 9.00 & 8.33 & 12.67 & $9.53 b$ & ** & ** & * \\
\hline & 0.125 & 11.67 & 9.00 & 9.33 & 11.00 & 11.67 & $10.53 a$ & & & \\
\hline & 0.250 & 11.67 & 8.33 & 8.67 & 10.00 & 12.67 & $10.27 a$ & & & \\
\hline Average(BAP) & & $11.45 \mathrm{~b}$ & $8.33 d$ & $9.00 \mathrm{c}$ & $9.78 c$ & $12.34 a$ & & & & \\
\hline \multicolumn{8}{|c|}{$\begin{array}{ll}\text { L.S.D. (0.05) } \\
\end{array}$} & 0.80 & 0.62 & 1.38 \\
\hline \multicolumn{11}{|c|}{ (b) Average shoot length (cm) / propagule: } \\
\hline & 0.000 & 7.87 & 5.17 & 6.33 & 7.47 & 8.00 & $6.97 c$ & $\star \star$ & ** & $\star \star$ \\
\hline & 0.125 & 7.10 & 7.17 & 7.37 & 7.17 & 7.33 & $7.23 b$ & & & \\
\hline & 0.250 & 8.67 & 7.37 & 7.77 & 7.40 & 9.17 & $8.07 a$ & & & \\
\hline Average(BAP) & & $7.88 a$ & $6.57 c$ & $7.16 \mathrm{~b}$ & $7.35 b$ & $8.17 a$ & & & & \\
\hline
\end{tabular}

(c) Average number of nodes formed / propagule:

\begin{tabular}{|c|c|c|c|c|c|c|c|c|c|c|}
\hline & 0.000 & 8.00 & 4.33 & 4.67 & 8.67 & 9.00 & $6.93 b$ & ** & $* *$ & $* *$ \\
\hline & 0.125 & 9.67 & 8.00 & 8.67 & 6.67 & 10.33 & $8.67 a$ & & & \\
\hline & 0.250 & 10.33 & 6.33 & 7.33 & 7.67 & 11.33 & $8.60 a$ & & & \\
\hline Average(BAP) & & $9.33 b$ & $6.22 e$ & $6.89 d$ & $7.67 c$ & $10.22 a$ & & & & \\
\hline \multicolumn{8}{|c|}{ L.S.D. (0.05) } & 0.61 & 0.47 & 1.06 \\
\hline
\end{tabular}

(d) Average number of leaflets formed / propagule:

\begin{tabular}{|c|c|c|c|c|c|c|c|c|c|c|}
\hline & 0.000 & 9.00 & 5.33 & 5.67 & 9.67 & 10.00 & $7.93 b$ & ** & ** & ** \\
\hline & 0.125 & 10.67 & 9.00 & 9.67 & 7.67 & 11.33 & $9.67 a$ & & & \\
\hline & 0.250 & 11.33 & 7.33 & 8.67 & 8.67 & 12.33 & $9.60 a$ & & & \\
\hline Average(BAP) & & $10.33 b$ & 7.22 & $7.89 d$ & $8.67 c$ & $11.22 \mathrm{a}$ & & & & \\
\hline \multicolumn{8}{|c|}{ L.S.D. (0.05) } & 0.61 & 0.47 & 1.06 \\
\hline
\end{tabular}

(e) Average number of roots formed / propagule:

\begin{tabular}{|c|c|c|c|c|c|c|c|c|c|c|}
\hline & 0.000 & 5.00 & 6.33 & 6.67 & 7.33 & 6.67 & $5.00 c$ & ** & ** & $\star \star$ \\
\hline & 0.125 & 5.33 & 6.67 & 7.00 & 7.67 & 9.00 & 7013 & & & \\
\hline & 0.250 & 5.33 & 5.67 & 6.33 & 9.33 & 11.67 & $7.67 a$ & & & \\
\hline Average(BAP) & & $5.22 d$ & $6.22 \mathrm{c}$ & $6.67 c$ & $8.11 b$ & $9.11 a$ & & & & \\
\hline \multicolumn{8}{|c|}{ L.S.D. (0.05) } & 0.61 & 0.47 & 1.10 \\
\hline
\end{tabular}

- Mean values followed by the same letter (s), are not different significantly.

- L.S.D. $(0.05)=$ Least significant difference test at 0.05 level of probability.

- ${ }^{*},{ }^{* \star}, \mathrm{NS}=$ significant, high significant, not significant, respectively. 
Table (4). The effect of different levels of BAP and NAA (mg/l) and their combinations on the multiplication stage using nodal cutting for Bellini potato cultivar after four weeks in vitro.

\begin{tabular}{|c|c|c|c|c|c|c|c|c|c|c|}
\hline \multirow[b]{2}{*}{ Characters } & \multirow{2}{*}{$\begin{array}{l}\text { NAA } \\
\text { levels } \\
(\mathrm{mg} / \mathrm{l})\end{array}$} & \multicolumn{5}{|c|}{ BAP levels (mg/l) } & \multirow{2}{*}{$\begin{array}{c}\text { Average } \\
\text { NAA }\end{array}$} & \multicolumn{2}{|c|}{ Significance } & \multirow{2}{*}{$\begin{array}{c}\text { BAP } \\
X \\
\text { NAA }\end{array}$} \\
\hline & & 0.00 & 0.25 & 0.50 & 1.00 & 2.00 & & \multirow[t]{2}{*}{ BAP } & NAA & \\
\hline \multicolumn{10}{|c|}{ (a) Average number of neoformed shoots / propagule } & \\
\hline & 0.000 & 11.00 & 6.67 & 9.00 & 8.33 & 12.67 & $9.53 \mathrm{~b}$ & ** & ** & ** \\
\hline & 0.125 & 11.67 & 9.00 & 9.33 & 11.00 & 11.67 & $10.53 a$ & & & \\
\hline & 0.250 & 11.67 & 8.33 & 8.67 & 10.00 & 12.67 & $10.27 a$ & & & \\
\hline Average(BAP) & & $11.89 a$ & $8.22 \mathrm{~d}$ & $9.89 \mathrm{c}$ & $11.11 \mathrm{~b}$ & $12.00 \mathrm{a}$ & & & & \\
\hline L.S.D. (0.05) & & & & & & & & 0.76 & 0.59 & 1.32 \\
\hline \multicolumn{11}{|c|}{ (b) Average shoot length (cm) / propagule: } \\
\hline & 0.000 & 8.57 & 5.87 & 7.03 & 8.20 & 8.83 & $7.70 \mathrm{c}$ & ** & ** & ** \\
\hline & 0.125 & 8.20 & 7.93 & 8.07 & 8.00 & 8.23 & $8.09 \mathrm{~b}$ & & & \\
\hline & 0.250 & 9.40 & 8.07 & 8.50 & 8.17 & 9.77 & $8.78 \mathrm{a}$ & & & \\
\hline Average(BAP) & & $8.72 \mathrm{a}$ & $7.29 \mathrm{~d}$ & $7.87 \mathrm{c}$ & $8.12 \mathrm{~b}$ & $8.94 a$ & & & & \\
\hline L.S.D. (0.05) & & & & & & & & 0.25 & 0.19 & 0.43 \\
\hline \multicolumn{11}{|c|}{ (c) Average number of nodes formed / propagule: } \\
\hline & 0.000 & 8.67 & 5.33 & 5.67 & 9.67 & 11.33 & $8.13 \mathrm{~b}$ & ** & ** & ** \\
\hline & 0.125 & 10.00 & 8.67 & 9.33 & 7.67 & 12.00 & $9.53 a$ & & & \\
\hline & 0.250 & 11.00 & 7.33 & 8.33 & 8.67 & 12.33 & $9.53 a$ & & & \\
\hline Average(BAP) & & $9.89 \mathrm{~b}$ & $7.11 \mathrm{e}$ & $7.78 \mathrm{~d}$ & $8.67 \mathrm{c}$ & $11.89 \mathrm{a}$ & & & & \\
\hline L.S.D. (0.05) & & & & & & & & 0.66 & 0.51 & 1.14 \\
\hline \multicolumn{11}{|c|}{ (d) Average number of leaflets formed / propagule: } \\
\hline & 0.000 & 9.67 & 6.33 & 6.67 & 10.67 & 12.33 & $9.13 \mathrm{~b}$ & ** & ** & ** \\
\hline & 0.125 & 11.00 & 9.67 & 10.33 & 8.67 & 13.00 & $10.53 a$ & & & \\
\hline & 0.250 & 12.00 & 8.33 & 9.33 & 9.67 & 13.33 & $10.53 a$ & & & \\
\hline Average(BAP) & & $10.89 \mathrm{~b}$ & $8.11 \mathrm{e}$ & $8.78 \mathrm{~d}$ & $9.67 \mathrm{c}$ & $12.89 \mathrm{a}$ & & & & \\
\hline L.S.D. (0.05) & & & & & & & & 0.66 & 0.51 & 1.14 \\
\hline \multicolumn{11}{|c|}{ (e) Average number of roots formed / propagule: } \\
\hline & 0.000 & 5.67 & 7.00 & 7.33 & 8.00 & 7.33 & $7.07 \mathrm{c}$ & ** & ** & ** \\
\hline & 0.125 & 5.33 & 7.67 & 7.67 & 8.67 & 9.67 & $7.80 \mathrm{~b}$ & & & \\
\hline & 0.250 & 6.33 & 7.00 & 7.33 & 9.00 & 12.67 & $8.47 a$ & & & \\
\hline Average(BAP) & & $5.78 d$ & $7.22 \mathrm{c}$ & $7.44 c$ & $8.56 \mathrm{~b}$ & $9.89 a$ & & & & \\
\hline L.S.D. (0.05) & & & & & & & & 0.73 & 0.57 & 1.27 \\
\hline
\end{tabular}

- Mean values followed by the same letter (s), are not different significantly.

- L.S.D. (0.05) = Least significant difference test at 0.05 level of probability.

$-{ }^{*},{ }^{* \star}, \mathrm{NS}=$ significant, high significant, not significant, respectively. 


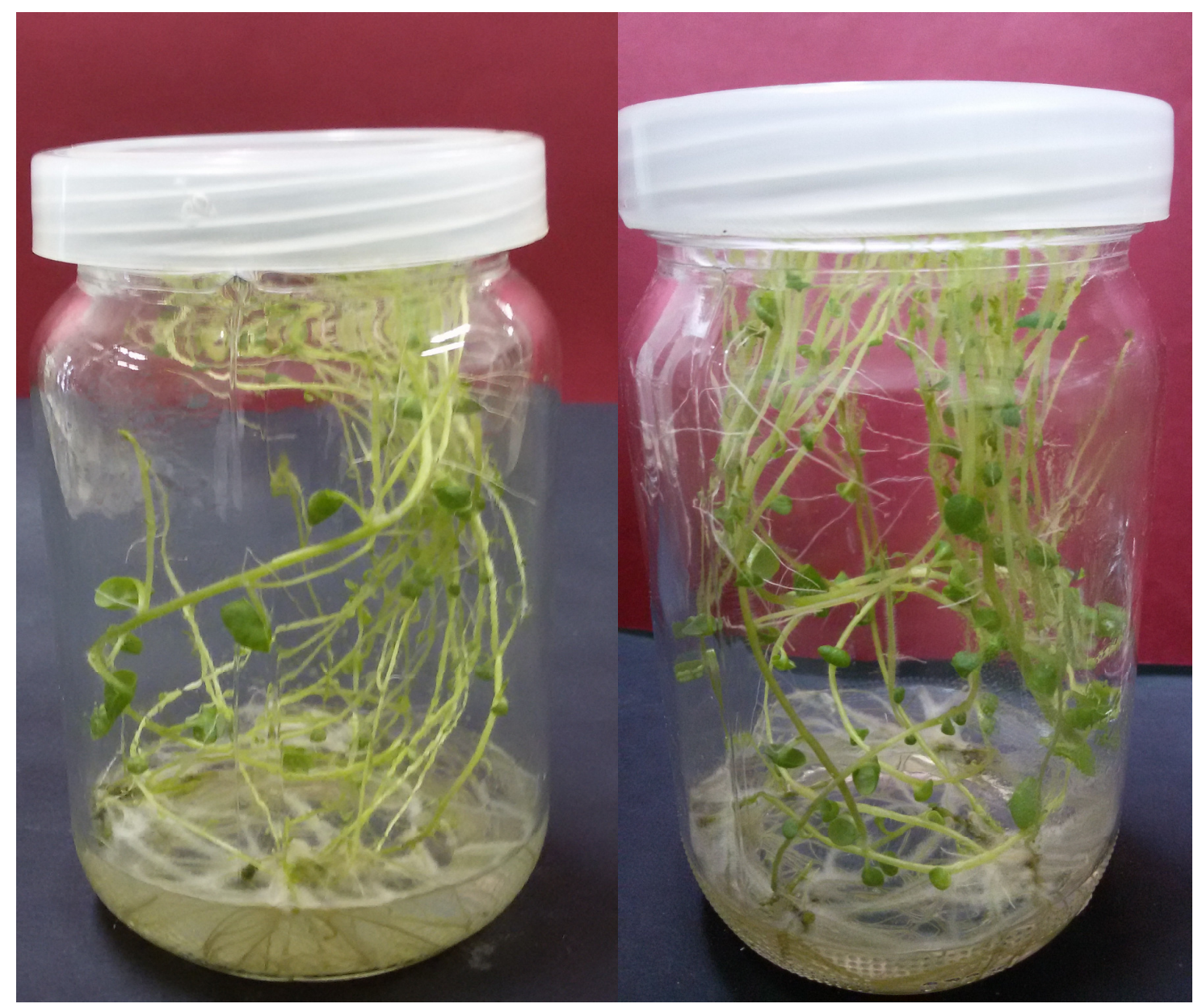

Figure (3): Lady Balfour cv.

Figure (4): Bellini cv.

Figures (3and4). Multiplication stage of both potato cultivars from newly formed nodal cuttings of initiation stage, upon culturing then for 4 weeks on MS medium fortified with BAP and NAA at 2.00 and $0.25 \mathrm{mg} / \mathrm{l}$, consecutively. 


\section{Rooting (rhizogenesis) stage:}

The results of rooting (rhizogenesis) stage of both tested cultivars are presented in Tables (5and 6 ) and Figures (5 and 6). The presented results of both cultivars expressed similar trend; whereas, the various levels of both IBA and NAA $(\mathrm{mg} / \mathrm{l})$ and their interaction exerted significant effects on the studied traits.

Respecting the main effect of IBA on rooting stage of both "Lady Balfour and Bellini" cvs, the obtained results revealed that IBA - free - medium $(0.00 \mathrm{mg} / \mathrm{l})$, brought about the highest averages of shoot length for both cultivars, viz. 8.18 and $8.68 \mathrm{~cm}$, each in turn. Meanwhile, augmenting the culture media for both tested cultivars, i.e. "Lady Balfour and Bellini" cvs. with $0.500 \mathrm{mg} / \mathrm{l} \mathrm{IBA}$, resulted in the highest averages of number of nodes, viz. 8.67 and 9.47, in series. Also, fortifying the culture media with $1.00 \mathrm{mg} / \mathrm{l} \mathrm{IBA}$ for both tested cultivars, i.e. "Lady Balfour and Bellini" led to the highest averages of root length and number of roots per propagule, as $8.75 \mathrm{~cm}$ and 15.07 for the former, and $9.17 \mathrm{~cm}$ and 16.13 for the later.

Respecting the main effect of NAA, the recorded results showed that adding NAA - free - media $(0.00 \mathrm{mg} / \mathrm{l})$, led to the highest averages of shoot length of both "Lady Balfour and Bellini" cvs. as 7.46 and $8.00 \mathrm{~cm}$, respectively. Likewise, fortifying the culture media with NAA at $0.250 \mathrm{mg} / \mathrm{l}$, led to the highest averages of number of nodes per propagule for both "Lady Balfour and Bellini" cvs., as 8.60 and 9.40 , orderly. Meanwhile, augmenting the culture media with NAA at 0.500 $\mathrm{mg} / \mathrm{l}$, resulted in the highest averages of both root length and number per propagule as $7.73 \mathrm{~cm}$ and 12.30 for the former and $8.32 \mathrm{~cm}$ and 13.10 for the later, in order.

Pertaining the interaction between the various tested levels of both applied growth regulators, showed that augmenting the culture medium with nil levels (plant growth regulators - free - medium) led to the highest averages of shoot length for "Lady Balfour and Bellini" cvs., as 8.88 , and $9.36 \mathrm{~cm}$, respectively.

Also, adding NAA at 0.250 without IBA to the highest averages of number of nodes per propagule for both cultivars as 9.00 and 9.60, each in turn. Likewise, adding IBA and NAA at 1.000 and 0.500 , respectively, led to the highest averages of root length for "Lady Balfour and Bellini" cvs., as 9.46 and $9.64 \mathrm{~cm}$, consecutively. Likewise, at the above - mentioned combination of both levels of growth regulators, led to the highest averages of number of roots per propagule as 16.80 for the former cultivar and 18.20 for the latter one.

This results coud be explaind on the bases that auxin induced number of responses which involved cell division, cell enlargement, protein and nucleic acids synthesis which are concomitants of auxin-induced growth and changes in wall plasticity of plant cell and increase the apical dominance as there are essential and 
rapid processes involved in growth and elongation (Wilkins,1989). The obtained results in this study were further confirmed by the previous findings of Komalavalli and Rao (2000); Sarker and Shaheen (2001); Munshi et al. (2004); Awal et al. (2005); Rajani and Patil (2009); Waseem et al. (2011) who suggested IBA as the best auxin for root induction and development.

Table (5). The effect of different levels of IBA and NAA (mg/l) and their combinations on the rooting stage of Lady Balfour potato culture cultivar after four weeks in vitro.

\begin{tabular}{|c|c|c|c|c|c|c|c|c|c|}
\hline \multirow[b]{2}{*}{ Characters } & \multirow{2}{*}{\begin{tabular}{|c|} 
NAA \\
levels \\
(mg/l)
\end{tabular}} & \multicolumn{4}{|c|}{ IBA levels (mg/l) } & \multirow{2}{*}{$\begin{array}{c}\text { Average } \\
\text { NAA }\end{array}$} & \multicolumn{2}{|c|}{ Significance } & \multirow{2}{*}{$\begin{array}{c}\text { IBA } \\
\text { X } \\
\text { NAA }\end{array}$} \\
\hline & & 0.000 & 0.250 & 0.500 & 1.000 & & IBA & NAA & \\
\hline \multicolumn{10}{|c|}{ (a) Average shoot length $(\mathrm{cm}) /$ propagule: } \\
\hline & 0.000 & 8.88 & 7.60 & 7.90 & 5.46 & $7.46 a$ & ** & ** & ** \\
\hline & 0.250 & 8.10 & 7.46 & 6.48 & 5.26 & $6.83 b$ & & & \\
\hline & 0.500 & 7.56 & 6.46 & 5.60 & 4.50 & $6.03 c$ & & & \\
\hline Average(IBA) & & $8.18 \mathrm{a}$ & $7.17 \mathrm{~b}$ & $6.66 \mathrm{c}$ & $5.07 \mathrm{~d}$ & & & & \\
\hline \multicolumn{7}{|c|}{ L.S.D. (0.05) } & 0.21 & 0.18 & 0.36 \\
\hline \multicolumn{10}{|c|}{ (b) Average number of nodes formed / propagule: } \\
\hline & 0.000 & 7.40 & 6.20 & 8.60 & 5.40 & $6.90 \mathrm{c}$ & ** & ** & ** \\
\hline & 0.250 & 9.00 & 8.40 & 8.60 & 8.40 & $8.60 a$ & & & \\
\hline & 0.500 & 7.00 & 7.40 & 8.80 & 7.40 & $7.65 \mathrm{~b}$ & & & \\
\hline Average(IBA) & & $7.80 \mathrm{~b}$ & $7.33 \mathrm{c}$ & $8.67 a$ & $7.07 \mathrm{c}$ & & & & \\
\hline \multicolumn{7}{|c|}{ L.S.D. (0.05) } & 0.44 & 0.38 & 0.76 \\
\hline \multicolumn{10}{|c|}{ (c) Average root length (cm) / propagule: } \\
\hline & 0.000 & 5.46 & 7.66 & 7.66 & 7.88 & $7.17 \mathrm{c}$ & ** & ** & ** \\
\hline & 0.250 & 5.72 & 7.20 & 7.78 & 8.90 & $7.40 \mathrm{~b}$ & & & \\
\hline & 0.500 & 5.92 & 7.08 & 8.44 & 9.46 & $7.73 a$ & & & \\
\hline Average(IBA) & & $5.70 \mathrm{~d}$ & $7.31 \mathrm{c}$ & $7.96 \mathrm{~b}$ & $8.75 \mathrm{a}$ & & & & \\
\hline \multicolumn{7}{|c|}{ L.S.D. (0.05) } & 0.26 & 0.23 & 0.46 \\
\hline \multicolumn{10}{|c|}{ (d) Average number of roots formed / propagule: } \\
\hline & 0.000 & 5.40 & 8.60 & 9.60 & 12.40 & $9.00 \mathrm{c}$ & ** & ** & ** \\
\hline & 0.250 & 8.40 & 9.80 & 13.00 & 16.00 & $11.80 \mathrm{~b}$ & & & \\
\hline & 0.500 & 9.80 & 10.20 & 12.40 & 16.80 & $12.30 \mathrm{a}$ & & & \\
\hline Average(IBA) & & $7.87 \mathrm{~d}$ & $9.53 \mathrm{c}$ & $11.67 \mathrm{~b}$ & $15.07 a$ & & & & \\
\hline \multicolumn{7}{|c|}{ L.S.D. (0.05) } & 0.57 & 0.49 & 0.98 \\
\hline
\end{tabular}

- Mean values followed by the same letter (s), are not different significantly.

- L.S.D. (0.05) = Least significant difference test at 0.05 level of probability.

$-{ }^{*},{ }^{* *}, \mathrm{NS}=$ significant, high significant, not significant, respectively. 
Table (6): The effect of different levels of IBA and NAA (mg/l) and their combinations on the rooting stage of Bellini potato culture cultivar after four weeks in vitro.

\begin{tabular}{|c|c|c|c|c|c|c|c|c|c|}
\hline \multirow[b]{2}{*}{ Characters } & \multirow{2}{*}{$\begin{array}{c}\text { NAA } \\
\text { levels } \\
\text { (mg/l) }\end{array}$} & \multicolumn{4}{|c|}{ IBA levels (mg/l) } & \multirow{2}{*}{$\begin{array}{c}\text { Average } \\
\text { NAA }\end{array}$} & \multicolumn{2}{|c|}{ Significance } & \multirow{2}{*}{$\begin{array}{c}\text { IBA } \\
X \\
\text { NAA }\end{array}$} \\
\hline & & 0.000 & 0.250 & 0.500 & 1.000 & & IBA & NAA & \\
\hline \multicolumn{10}{|c|}{ (a) Average shoot length (cm) / propagule: } \\
\hline & 0.000 & 9.36 & 8.16 & 8.46 & 5.98 & $8.00 \mathrm{a}$ & ** & ** & ** \\
\hline & 0.250 & 8.62 & 8.06 & 7.02 & 5.88 & $7.40 \mathrm{~b}$ & & & \\
\hline & 0.500 & 8.06 & 6.96 & 6.16 & 5.04 & $6.56 \mathrm{c}$ & & & \\
\hline Average (IBA) & & $8.68 \mathrm{a}$ & $7.73 b$ & $7.21 \mathrm{c}$ & 5.63d & & & & \\
\hline \multicolumn{7}{|c|}{ L.S.D. (0.05) } & 0.22 & 0.19 & 0.39 \\
\hline \multicolumn{10}{|c|}{ (b) Average number of nodes formed / propagule: } \\
\hline & 0.000 & 8.40 & 7.20 & 9.60 & 6.40 & $7.90 \mathrm{c}$ & ** & ** & ** \\
\hline & 0.250 & 9.60 & 9.40 & 9.40 & 9.20 & $9.40 a$ & & & \\
\hline & 0.500 & 8.00 & 8.40 & 9.40 & 8.40 & $8.55 b$ & & & \\
\hline Average (IBA) & & $8.67 \mathrm{~b}$ & $8.33 b c$ & $9.47 a$ & $8.00 \mathrm{c}$ & & & & \\
\hline \multicolumn{7}{|c|}{ L.S.D. (0.05) } & 0.46 & 0.39 & 0.79 \\
\hline \multicolumn{10}{|c|}{ (c) Average root length (cm) / propagule: } \\
\hline & 0.000 & 5.64 & 8.26 & 8.24 & 8.46 & $7.65 \mathrm{c}$ & ** & ** & ** \\
\hline & 0.250 & 6.26 & 7.82 & 8.38 & 9.40 & $7.97 \mathrm{~b}$ & & & \\
\hline & 0.500 & 6.64 & 7.80 & 9.20 & 9.64 & $8.32 a$ & & & \\
\hline Average (IBA) & & $6.18 \mathrm{~d}$ & $7.96 \mathrm{c}$ & $8.61 \mathrm{~b}$ & $9.17 a$ & & & & \\
\hline \multicolumn{7}{|c|}{ L.S.D. (0.05) } & 0.30 & 0.26 & 0.52 \\
\hline \multicolumn{10}{|c|}{ (d) Average number of roots formed / propagule: } \\
\hline & 0.000 & 5.80 & 9.40 & 9.80 & 13.20 & $9.55 c$ & ** & $\star \star \star$ & ** \\
\hline & 0.250 & 8.80 & 10.80 & 13.60 & 17.00 & $12.55 \mathrm{~b}$ & & & \\
\hline & 0.500 & 10.40 & 11.00 & 12.80 & 18.20 & $13.10 \mathrm{a}$ & & & \\
\hline Average (IBA) & & $8.33 d$ & $10.40 \mathrm{c}$ & $12.07 \mathrm{~b}$ & $16.13 a$ & & & & \\
\hline \multicolumn{7}{|c|}{ L.S.D. (0.05) } & 0.46 & 0.40 & 0.80 \\
\hline
\end{tabular}

- Mean values followed by the same letter (s), are not different significantly.

- L.S.D. (0.05) = Least significant difference test at 0.05 level of probability.

$-{ }^{*},{ }^{* *}, \mathrm{NS}=$ significant, high significant, not significant, respectively. 


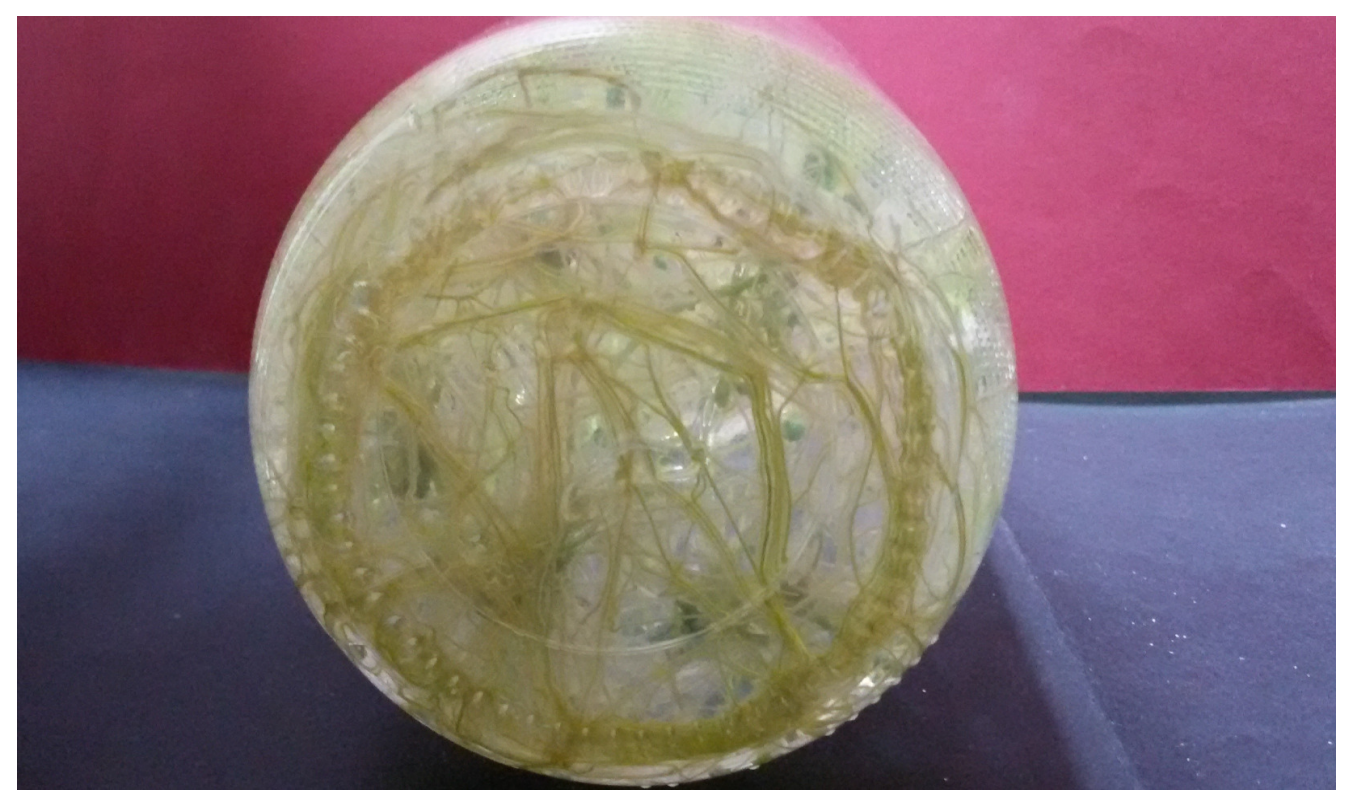

Figure (5): Lady Balfour cv.

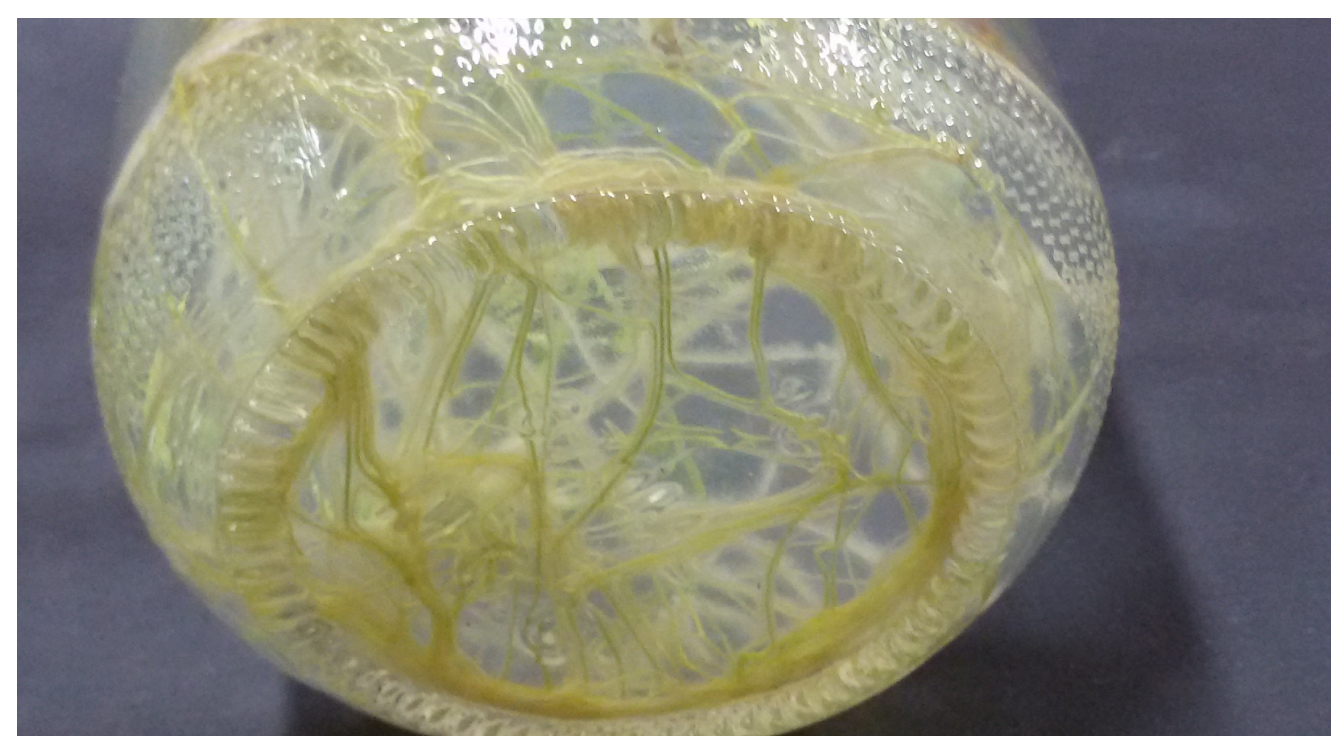

Figure (6): Bellini cv.

Figures (5 and 6). Rhizogenesis stage of both potato cultivars microshoots of multiplication stage, upon culturing then for 4 weeks on MS medium augmented with IBA and NAA at 1.00 and 0.50 $\mathrm{mg} / \mathrm{l}$, each in turn. 


\section{Acclimatization stage:}

Respecting the effect of mixtures of perlite and peatmoss $(\mathrm{v} / \mathrm{v})$ and their combinations, in addition to fixed volume (1 portion) of sand on acclimatization of neoformed plantlets of both tested cultivars, i.e. Lady Balfour and Bellini are shown in Tables (7and 8), each in turn. However, results depicted in both Tables revealed affecting the studied traits under the study, significantly, by both variables and their interactions.

Generally, the obtained results expressed a proportionate relationship between the tested levels of each variable and the studied traits. For instance, the main effect of perlite levels $(\mathrm{v} / \mathrm{v})$ showed that as its volumes increased, the given trait averages increased. Concerning "Lady Balfour" cv., the highest averages of the survival percentage, plant height, and number of neoformed branches per plant were $82.81 \%, 8.85$ and 6.63, respectively, for "Lady Balfour" cv. and 75.06\%, 8.08 $\mathrm{cm}$ and 5.81, consecutively, for "Bellini" cv. Meanwhile, the lowest averages of studied traits were achieved at nil level $(0.0 \mathrm{v} / \mathrm{v})$ of perlite.

As for the main effect of peatmoss, there were a direct proportionate relationship between it and the averages of the studied characteristics, too. Whereas, the highest trait averages were recorded when potting mix contained $(3.0 \mathrm{v} / \mathrm{v})$ volumes and vice versa. However, the highest averages of the survival percentage, plant height, and number of neoformed branches per plant for "Lady Balfour" cv. were $84.38 \%, 7.88 \mathrm{~cm}$ and 5.88 , respectively. On the other side, the highest averages of the same characteristics of "Bellini" cv. were $78.13 \%, 7.17 \mathrm{~cm}$ and 5.25 , consecutively.

With respect to the interaction between both variables, it was clear that adding perlite and peatmoss in equal volumes (3:3), brought the highest averages of the studied traits of both cultivars. As for "Lady Balfour" cv. the highest studied traits were more or less, $100 \%, 11 \mathrm{~cm}$ and 7.5 , for survival percentage, plant height, and number of neoformed branches, respectively. On other hand, the highest studied traits averages of Bellini cultivar were $100 \%, 9.63 \mathrm{~cm}$ and 7.00 , for the above - mentioned each, orderly.

In this respect, material as peatmoss is one of the most important constituents of media due to its capacity in affecting plant growth either indirectly or directly. Indirectly, improves the physical conditions of media by enhancing aggregation, aeration ( $8 \%$ ) and water retention (77\%), thereby creating a suitable environment for root growth (Sensi and Loffredo, 1999). On the other hand, perlite is known to have a moderate capacity to retain water (38\%) and provide' aeration $(25 \%)$ and its neural $\mathrm{pH}$ and the fact that it is sterile and weed-free. Hence, it is ideal for use in container growing substratum (Abido, 2016). Also, it is known that perlite decreases the bulk density of the soils and increases the porosity. 
A mixture of peat moss and sand in the ratio of $4: 1$ proved best for growing plantlets of potato (Sanavy and Moeini, 2003). In conclusion, it is possibe to propagate both potato cultivars coined Lady Balfour and Bellini in vitro under reproducible and reliable technique. This protocol will provide the base for the mass production of studied cultivars through in vitro technique. Also, the mixture of varying proportions as perlite, peatmoss and sand (3:3:1) can be designated to take advantage of the positive characteristics of each substratum and their interactions, in order to create optimal characteristics of plant growth (best water retention, $\mathrm{pH}$ levels, porosity, aeration .......etc.) along with a fixed proportion of washed sand.

Table (7). The effect of different potting mixtures of Perlite and Peatmoss $(\mathrm{v} / \mathrm{v})$ and their combinations on the acclimatization of neoformed plantlets of Lady Balfour cultivar after four weeks ex vitro.

\begin{tabular}{|c|c|c|c|c|c|c|c|c|c|}
\hline \multirow[b]{2}{*}{ Characters } & \multirow{2}{*}{$\begin{array}{c}\text { Peat. } \\
\text { levels } \\
(\mathrm{v} / \mathrm{v})\end{array}$} & \multicolumn{4}{|c|}{ Perlite levels (v/v) } & \multirow{2}{*}{$\begin{array}{c}\text { Average } \\
\text { Peat. }\end{array}$} & \multicolumn{2}{|c|}{ Significance } & \multirow[b]{2}{*}{$\begin{array}{c}\text { Per. X } \\
\text { Peat. }\end{array}$} \\
\hline & & 0.00 & 1.00 & 2.00 & 3.00 & & Per. & Peat. & \\
\hline \multicolumn{10}{|c|}{ (a) Average survival percentage (\%) / plant } \\
\hline & 0.00 & 00.00 & 43.75 & 62.50 & 65.25 & 40.63d & ** & ** & *夫 \\
\hline & 1.00 & 50.00 & 62.50 & 50.00 & 81.25 & $60.94 \mathrm{c}$ & & & \\
\hline & 2.00 & 50.00 & 62.50 & 87.50 & 93.75 & $73.44 b$ & & & \\
\hline & 3.00 & 62.50 & 81.25 & 93.75 & 100.00 & $84.38 \mathrm{a}$ & & & \\
\hline Average(Per.) & & $40.63 d$ & $62.50 \mathrm{c}$ & $73.44 b$ & $82.81 \mathrm{a}$ & & & & \\
\hline \multicolumn{7}{|c|}{ L.S.D. (0.05) } & 7.91 & 7.91 & 15.81 \\
\hline \multicolumn{10}{|c|}{ b) Average plant height (cm) / plant: } \\
\hline & 0.00 & 0.00 & 4.50 & 5.70 & 6.80 & $4.25 d$ & ** & *夫 & ** \\
\hline & 1.00 & 4.30 & 5.90 & 6.80 & 8.40 & $6.35 \mathrm{c}$ & & & \\
\hline & 2.00 & 5.10 & 6.50 & 7.30 & 9.20 & $7.03 \mathrm{~b}$ & & & \\
\hline & 3.00 & 5.30 & 6.70 & 8.50 & 11.00 & $7.88 \mathrm{a}$ & & & \\
\hline Average(Per.) & & $3.68 \mathrm{~d}$ & $5.90 \mathrm{c}$ & $7.08 \mathrm{~b}$ & $8.85 \mathrm{a}$ & & & & \\
\hline \multicolumn{7}{|c|}{ L.S.D. (0.05) } & 0.29 & 0.29 & 0.59 \\
\hline \multicolumn{10}{|c|}{ (c) Average number of neoformed branches / plant: } \\
\hline & 0.00 & 0.00 & 3.25 & 4.50 & 5.50 & $3.31 d$ & ** & ** & ** \\
\hline & 3.00 & 3.00 & 3.75 & 5.00 & 6.50 & $4.56 \mathrm{c}$ & & & \\
\hline & 3.50 & 3.50 & 4.75 & 5.75 & 7.00 & $5.25 \mathrm{~b}$ & & & \\
\hline & 4.50 & 4.50 & 5.50 & 6.00 & 7.50 & $5.88 \mathrm{a}$ & & & \\
\hline Average(Per.) & & $2.75 \mathrm{~d}$ & $4.31 \mathrm{c}$ & $5.31 \mathrm{~b}$ & $6.63 a$ & & & & \\
\hline \multicolumn{7}{|c|}{ L.S.D. (0.05) } & 0.46 & 0.46 & 0.92 \\
\hline
\end{tabular}

- Mean values followed by the same letter (s), are not different significantly.

- L.S.D. (0.05) = Least significant difference test at 0.05 level of probability.

- * ${ }^{* *}, \mathrm{NS}=$ significant, high significant, not significant, respectively. 
Table (8). The effect of different potting mixtures of Perlite and Peatmoss (v/v) and their combinations on the acclimatization of neoformed plantlets of Bellini cultivar after four weeks ex vitro.

\begin{tabular}{|c|c|c|c|c|c|c|c|c|c|}
\hline \multirow[b]{2}{*}{ Characters } & \multirow{2}{*}{$\begin{array}{l}\text { Peat. } \\
\text { levels } \\
\text { (v/v) }\end{array}$} & \multicolumn{4}{|c|}{ Perlite levels (v/v) } & \multicolumn{3}{|c|}{ Average Significance } & \multirow{2}{*}{ Per. X Peat. } \\
\hline & & 0.00 & 1.00 & 2.00 & 3.00 & Peat. & Per. & Peat. & \\
\hline \multicolumn{10}{|c|}{ (a) Average survival percentage (\%) / plant } \\
\hline & 0.00 & 00.00 & 50.00 & 56.25 & 50.00 & $39.06 a$ & ** & ** & ** \\
\hline & 1.00 & 50.00 & 68.75 & 50.00 & 68.75 & $59.34 \mathrm{c}$ & & & \\
\hline & 2.00 & 50.00 & 56.25 & 81.25 & 87.50 & $68.75 \mathrm{~b}$ & & & \\
\hline & 3.00 & 56.25 & 68.75 & 87.50 & 100.00 & $78.13 \mathrm{a}$ & & & \\
\hline \multirow{2}{*}{\multicolumn{2}{|c|}{ Average (Per.) }} & $39.06 \mathrm{~d}$ & $60.94 \mathrm{c}$ & $68.75 b$ & $75.06 a$ & & & & \\
\hline & & L.S.D & $(0.05)$ & & & & 6.91 & 6.91 & 13.81 \\
\hline \multicolumn{10}{|c|}{ (b) Average plant height (cm) / plant: } \\
\hline & 0.00 & 0.00 & 4.00 & 5.18 & 6.25 & $3.86 \mathrm{~d}$ & ** & ** & ** \\
\hline & 1.00 & 3.80 & 5.38 & 6.25 & 7.85 & $5.82 \mathrm{c}$ & & & \\
\hline & 2.00 & 4.63 & 5.88 & 6.75 & 8.58 & $6.46 \mathrm{~b}$ & & & \\
\hline & 3.00 & 4.75 & 6.23 & 8.08 & 9.63 & $7.17 a$ & & & \\
\hline \multirow[t]{2}{*}{ Average (Per.) } & & $3.30 \mathrm{~d}$ & $5.37 \mathrm{c}$ & $6.57 \mathrm{~b}$ & $8.08 \mathrm{a}$ & & & & \\
\hline & & L.S.D & $(0.05)$ & & & & 0.30 & 0.30 & 0.59 \\
\hline \multicolumn{10}{|c|}{ (c) Average number of neoformed branches / plant: } \\
\hline & 0.00 & 0.00 & 2.50 & 3.50 & 4.75 & $2.69 d$ & ** & ** & * \\
\hline & 3.00 & 2.75 & 3.50 & 4.00 & 5.50 & $3.94 \mathrm{c}$ & & & \\
\hline & 3.50 & 3.25 & 4.25 & 5.00 & 6.00 & $4.63 \mathrm{~b}$ & & & \\
\hline & 4.50 & 4.25 & 4.75 & 5.00 & 7.00 & $5.25 \mathrm{a}$ & & & \\
\hline Average (Per.) & & $2.56 \mathrm{~d}$ & $3.75 d$ & $4.38 \mathrm{~b}$ & $5.81 \mathrm{a}$ & & & & \\
\hline \multicolumn{7}{|c|}{ L.S.D. (0.05) } & 0.47 & 0.47 & 0.93 \\
\hline
\end{tabular}

- Mean values followed by the same letter (s), are not different significantly.

- L.S.D. (0.05) = Least significant difference test at 0.05 level of probability.

$-{ }^{*},{ }^{* *}, \mathrm{NS}=$ significant, high significant, not significant, respectively. 


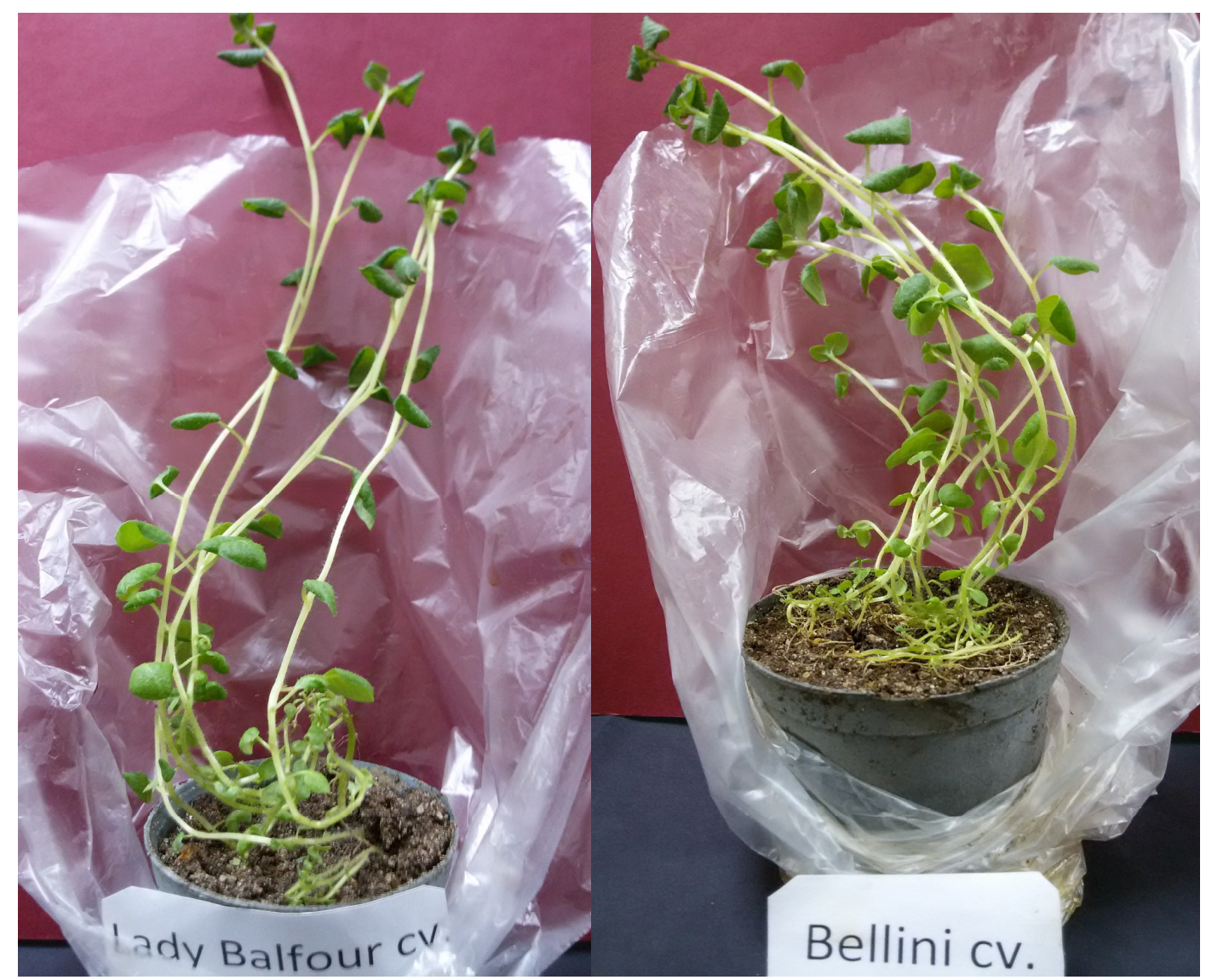

Figure (7). Lady Balfour cv.

Figure (8): Bellini cv

Figures (7and8). Acclimatization stage of neoformed plantlets of both potato cultivars ex vitro for 4 weeks on potting mixtures of sand, Perlite and Peatmoss (1:3:3), orderly.

\section{REFERNCES:}

Abido, A. I. (2016). Acclimatization of plant tissue culture - derived plants (Theory and Application). Dar El Hoda Pup. Alexandria, Egypt, 267 [In Arabic].

Ammirato, P. V. (2004). Yams In: Ammirato PV, Evans DA, Sharp WR, Yamada Y (eds) Handbook of plant cell culture. Macmillan NY, 3:329-354.

Awal, S. M. A., M. R. A. Alam and M. N. U. Hasan(2005). In vitro propagation of pointed gound (Trichosanthes dioica Roxb.) from shoot tips.

Biotech., 4(3): 221-224.

Azar, M. A., S. Kazemiani, F. Kiumarsie, N. Mohaddes (2011). Shoot Proliferation from node explants of potato (Solanum tuberosum cv. Agria). 
Effect of Different concentrations of $\mathrm{NH} 4 \mathrm{NO} 3$, hydrolyzed casein and BAP. Romanian Biotechnol, Letters, 16: 6181-6186.

Badoni, A. and J. S. Chauhan (2009). Effect of Growth Regulators on Meristemtip Development and in vitro multiplication of potato cultivar 'Kufri Himalini'. Nature and Science, 7(9): 3134.

Badoni, A. and J. S. Chauhan (2010). Potato seed production of cultivar Kufri Himalini, In vitro. Stem Cell, 1(1):1-6.

Ben-Jaacov, J., A. Ackerman, E. Tal and G. Jacobs (1991).Vegetative propagation of Alberta magna by tissue culture and grafting. Hort-Science 26, 74.

Boxus P.H. and J.M. Terzi (1988). Control of accidental contaminations during mass propagation. Acta Hortic. 225, 189-190.

Donnelly, D. J., W. K. Coleman and S. E. Coleman (2003). Potato microtuber production and performance: a review. American. J. Potato Res. 80: 103115.

Espinoza, N., R. Lizarraga, C. Siguenas and F. Buitron (1992). Tissue Culture: Micropropagation, Conservation and Export Of Potato Germplasm. Cip Research Guide 1, International Potato Center, Lima, Peru.

FAOSTAT. (2013). Production and area harvested statistics for potato for 2013. http://faostat3.fao.org/home/index.html\#downlaod. Accessed May 2015.

Fries, N. (1960). The effect of adenine and kinetin on growth and differentiation of Lupinus. Physiol. Plant. 13, 468-481.

George, E. F., M. A. Hall and G. J. D. Klerk (2008). Plant Propagation by tissue culture.3rd Edition.Springer.

Gomez, K. and A. A. Gomez (1984). Statistical procedures for Agricultural Research ( $2^{\text {nd }}$ ed.). An International Rice Research Institute Bok. A Wiley Inter science Publisher, New York.

Gopal, J., C. Anjali and S. Debabrata (2005). Use of microtubers for slow growth in vitro conservation of potato germplasm. Plant Genetic Resource Newsletter, 141: 56-60.

Haque, M.I., N.B. Mila, M. S. Khan and R. H. Sarker (1996). Shoot regeneration and in vitro micro tuber formation in potato (Solanum tubersom L.). Bang. J. Bot., 25: 87- 93.

Harris G. P. and E. M. H. Hart (1964). Regeneration from leaf squares of Peperomia sandersii A, DC: a relationship between rooting and budding. Ann. Bot., 28: 509-526.

Hoque, M. E. (2010). In vitro regeneration potentiality of potato under different hormonal combination. World J. of Agric. Sci., 6 (6): 660-663.

Hoque, M. I., M. A. Islam, R. H. Sarker and A. S. Islam (1996a). In vitro microtuber formation in potato (Solanum tubersoum L.). In: Plant Tissue Culture. (Ed): A.S. Islam, Oxford \& IBH, Publ. Co., Calcutta/New Delhi, pp. 221-228.

Hoque, M. I., N. B. Mila, M. S. Khan, R. H. Sarker and A. S. Islam (1996b). Shoot regeneration and in vitro microtuber formation in potato (Solanum tuberosum L.). Bangladesh J. Bot., 25(1): 87-93. 
Hossain, M. A., M. Shamimuzzaman, M. S. Islam, M. A. Mannan and M. D. Hossain (2009). Accli-matization of micropropagated potato plantlets from in vitro to ex vitro conditions. Intl. J. Bio. Res., 6 (1): 45-50.

Humphries, E. C. (1960). Kinetin inhibited root formation on leaf petioles of detached leaves of Phaseolus vulgaris (dwarf bean). Physiol. Plant., 13: 659-663.

Hussain, I., A. Muhammad, Z. Chaudhary, R. Asghar, S. M. S. Naqvi and H. Rashid (2005). Morphogenic potential of three potato (solanum tuberosum L) cultivars from diverse explants, a prerequisite in genetic manipulation. Pak. J. Bot., 37(4): 889-898.

Ilahi, I., M. Jabeen and S.N. Sadaf (2007). Rapid clonal propagation of chrysanthe-mum through embroyogenic callus formation. Pak. J. Bot., 39(6): 1945-1952.

Iqbal H., A. Muhammad, Z. Chaudhry, R. Asghar, S. M. S. Naqvi and H Rashid (2005). Morphogenic Potential Of Three Potato (Solanum tuberosum L.) ultivars From Diverse Explants, A Prerequisite In Genetic Manipulation. Pak. J. Bot., 37(4): 889-898, 2005.

Khatun, N., M. A. Bari, R. Islam, S. Huda, N. A. Siddque, M. A. Rahman, and M. U. Mullah (2003). Callus induction and regeneration from nodal segment of potato cultivar Diamant. J. Biol. Sci., 3, 1101-1106.

Komalavalli, N. and M.V. Rao (2000). In vitro micro-propagation of Gymnemam Slyvestre.Amultipurpose medicinal plant.PI.Cell,Tiss.Org.Cul.,61:97-105.

Konwar, B. K. and R. H. A. Coutts (1990). Rapid regeneration of sugar beet (Beta vulgaris L.) plants from in vitro cultures. pp. 114-118 in Nijkamp et al. (eds.) 1990 (q.v.).

Lam, S. L. (1977). Plantlet formation from potato tuber discs in vitro, Am. Pot. Journ., 54 (10): 465- 468.

Lee, T. T. (1974). Cytokinin control in subcellular localization of indoleacetic acid oxidase and peroxidase. Phytochemistry, 13: 2445-2453.

Liljana, K. G, S. Mitrev, T. Fidanka and I. Mite (2012). Micropropagation of Potato (Solanum tuberosum L). Electr. J. Biol., 8(3): 45-49.

Mila, N.B. (1991). Optimization of in vitro microtubers formation in potato (Solanum tuberosum L.). M.Sc. Thesis, Plant Breeding and Tissue Culture Lab., Department of Botany, University of Dhaka.

Moeinil, M. J., M. Armin, M. R. Asgharipour and S. K. Yazdi (2011). Effects of different plant growth regulators and potting mixes on micro-propagation and minituberization of potato plantlets. Adv. Environ. Bio., 5 (4): 631- 638.

Molla, M. M. H, K. M. Nasiruddin, M. Al-Amin, D. Khanam and M. A. Salam (2011). Effect of Growth Regulators on Direct Regeneration of Potato. International Conference on Environment and Industrial Innovation, vol.12, IACSIT Press, Singapore.

Munshi, M. K., L. Hakim, M. R. Islam and G. Ahmed (2004). In vitro clonal propagation of Banyan(Ficus benghalensis L.) through axillary bud culture. Int. J. Agric. Biol., 6(2): 321-323. 
Murashige, T. and F. Skoog (1962). A revised medium for rapid growth and bioassays with tobacco tissue cultures. Physiol Plant 15(3): 473-497.

Naik, P. S. and J. L. Karihaloo (2007). Micropropagation for Production of Quality Potato Seed in Asia-Pacific. Asia-Pacific Consortium on Agricultural Biotechnology, New Delhi, India. P. 47+viii.

Nemeth, G. (1979). Benzyladenine-stimulated rooting in fruit-tree rootstocks cultured in vitro. Z. Pflanzenphysiol., 95: 389-396.

Nistor, A., G. Campeanu, N. Atanasiu , N. Chiru and D. Karacsonyi (2010). Influence of potato genotypes on in vitro production of microtubers. Romanian biotechnol. Letters, 15 (3) : 1 - 8.

Pennazio, S., and M. Vecchiati (1976). Effect of naphthalene acetic acid on meristem tips development. Potato Research, 19(3): 232-234.

Pospisilova, J., I. Ticha, P. Kadlecek, , Haisel, D. and S. Pizakova (1999). Acclimatization of micropropagated plants to ex vitro conditions. Biol. Plant., 42: 481-497.

Rajani, H. and S.S. Patil. (2009). In vitro response of different explants' types on shoot and root development of Ginger. ISHS Acta Hort. 829: VI Inter. Symp. in vitro Cult. Hort. Breeding.

Sanavy, S. and M. J. Moieni (2003). Effects of different hormone combinations and planting beds on growth of single nodes and plantlets resulted from potato meristem culture. Plant Tissue Cult., 13(2):145-150.

Sarker, R. H. and I.Shaheen (2001). In Vitro propagation of chrysanthemum (Chrysanthemum morifolium Ramat) through allus.PI.Tiss.Cult.,11(1):85 91.

Sarker, R.H. and B.M. Mustafa (2002). Regeneration and AgrobacteriumMediated Genetic Transformation of two indigenous Potato varieties of Bangladesh. PI. Tiss. Cult., 12(1): 69-77.

Schraudolf, H. and J. Reinert (1959). Interaction of plant growth regulators in regeneration processes. Nature, 184: 465-466.

Sensi N, E. Loffredo (1999). The chemistry of soil organic matter. In: Spark, D.L. (Ed.), Soil Physical Chemistry. CRC Press, Boca Raton, FL, pp. 239-370.

Steel, R. G. D., J. H. Torrie and D. A. Dickie. (1997). Principles and procedures of statistics-a biometric approach. Third edition. McGraw-Hill Publishing Company. Toronto.

Tamas, I. A. (1987). Hormonal regulation of apical dominance. In: P. J. Davis (ed.). Plant hormones and their role in plant growth anddevelopment. Mortinus Nijoff Publishers.Dordrecht, PP. 397-410.

Trigiano, R.N. and D.J. Gray (2000). Editors, Plant Tissue Culture Concepts and Laboratory Exercises 2 nd Edition, CRC Press,Boca Raton,430 pp.

Uddin, S. N. (2002). In vitro propagation of Elite indigenous potato (Solanum tuberosum L. var Indurkani S. N. S. N.) of Bangladesh. Journal of Plant Sciencesi, 3: 212-216 (2002).

Waseem, K., M. S. Jilani, M. S. Khan, M. Kiran and G. khan (2011). Efficient in vitro regeneration of chrysanthemum (Chrysanthemum morifolium L.) plantlets from nodal segments.Afri.J.Biotechn.,10(8):1477-1484. 
Wilkins, M. B. (1989). Advanced plant physiology.The Bath Press,Avon,13-15 Yasmin, S., K.M. Nasiruddin, R. Begum and S.K. Talukder (2003). Regeneration and establishment of potato plantlets through callus formation with BAP and NAA. Asian J. Plant Sci., 2: 936-940.

Yousef, A. A. R., M. A. Suwwan, A. M. Musa and H. A. Abu-Qaoud (2001). In vitro culture and microtuberization of spunta potato (Solanum tuberosum $L$ ). DirasatAgric. Sci., 24: 173-181.

الملخص العربي

الإكثار المعملي الدقيق والأقلمة خارج أوعية الزراعة للبطاطس بإستخدام العقد الساقية كأجزاء نباتية

$$
\begin{aligned}
& \text { ' محمد حمود علي عثمان، ‘ علي إبراهيم علي عبيدو، ‘علي عدنان عوض جبل } \\
& \text { ' هيئة البحوث الزراعية - وزارة الزراعة والري - الجمهورية اليمنية } \\
& \text { 2ق قسم الإنتاج النباتي - كلية الزراعة (سابا باشا) - جامعة الإسكندرية }
\end{aligned}
$$

يعد محصول البطاطس محصول درني إقتصادي واسع الإنتشار في المناطق المعتلة والإسنوائية وشبه الإسنوائية. فهو

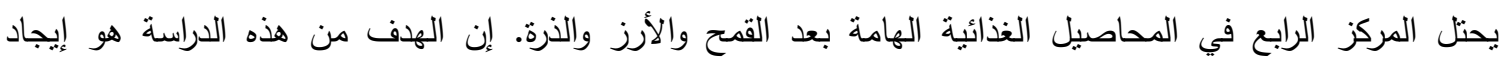

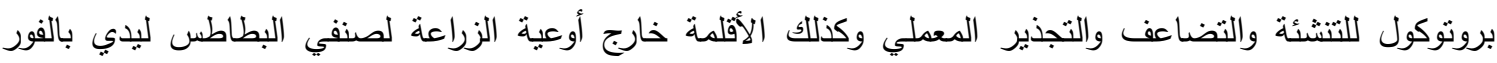
والبيليني. نم تتفيد هذه الدراسة في معمل زراعة الأنسجة النباتية - قسم الإنتاج النباتي كلية الزراعة (سابا بانشا) -

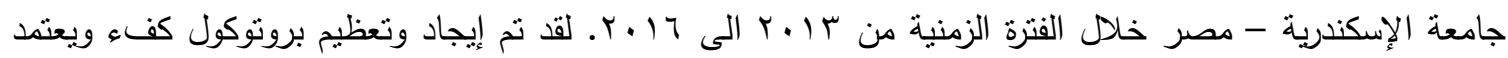
عليه للإكثار المعطلي الدقيق والأقلمة في البطاطس. تمت زراعة العقل الساقية كأجزاء نباتية على بيئات التتشئة بتركيزات مختلفة من الأوكسين NAA والكينتين KIN وكانت المجاميع الخضرية الناشئة قد زرعت على بيئات التضاعف (التكاثر) والتي تضمنت نركيزات مختلفة من الأوكسين NAA والسيتوكينين BAP لتكوين مجاميع خضرية عديدة وبيئات لاستطالة المجاميع الخضرية حديثة التكوين. وكانت المجاميع الخضرية التي اسنطالت قد نم تجذيرها، وأقلىت بنجاح خارج أوعية الزراعة. وكانت أفضل بيئة للتشئة هي بيئة مورشيج وسكوج MS المزودة بالكينتين عند املجم/لتز • والبيئة المفضلة للتضاعف كانت البيئة المختبرة والمزودة بالسيتوكينين BAP بتركيز ؟ ملجم/لتز ، والأوكسين

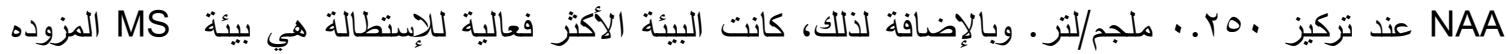
بالأوكسين NAA بتركيز .r. ب. ملجم/لتر • والأكثر من ذلك، أوضحت المجاميع الخضرية قوة وصحة وكونت جذوراً

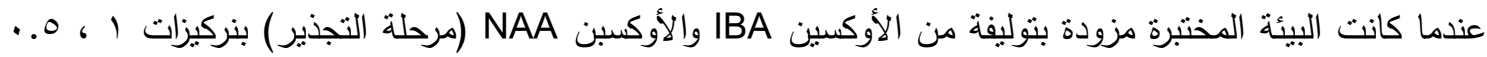

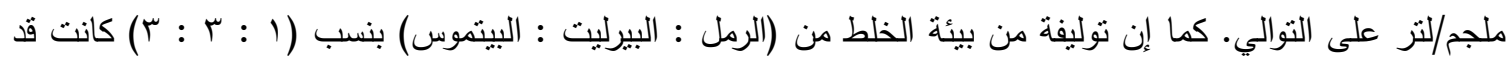

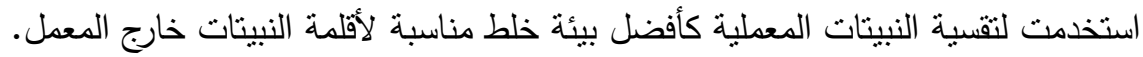


